\title{
Introducing new lightning schemes into the CHASER (MIROC) chemistry climate model
}

Yanfeng $\mathrm{He}^{1}$, Hossain Mohammed Syedul Hoque ${ }^{1}$, Kengo Sudo ${ }^{1,2}$

${ }^{1}$ Graduate School of Environment Studies, Nagoya University, Nagoya, 464-8601, Japan

$5 \quad{ }^{2}$ Japan Agency for Marine-Earth Science and Technology (JAMSTEC), 237-0061, Yokohama, Japan

Correspondence to: Yanfeng He (hyf412694462@gmail.com)

\begin{abstract}
The formation of nitrogen oxides $\left(\mathrm{NO}_{\mathrm{x}}\right)$ associated with lightning activities (hereinafter designated as $\left.\mathrm{LNO}_{\mathrm{x}}\right)$ is a major source of $\mathrm{NO}_{x}$. In fact, it is regarded as the most dominant $\mathrm{NO}_{\mathrm{x}}$ source in the upper troposphere. Therefore, improve the prediction accuracy of lightning and $\mathrm{LNO}_{\mathrm{x}}$ in chemical climate models is crucially important. This study implemented two new lightning schemes with the CHASER (MIROC) global chemical transport/climate model. The first lightning scheme is based on upward cloud ice flux (ICEFLUX scheme), whereas the second, also adopted in the European Centre for MediumRange Weather Forecasts (ECMWF) forecasting system (original ECMWF scheme). In the case of the original ECMWF scheme, by tuning the equations and adjustment factors for land and ocean, a modified ECMWF scheme was also tested in CHASER. In the original version of CHASER (MIROC), lightning is initially parameterized with the widely used cloud top height scheme (CTH scheme). Model evaluations with lightning observations conducted using an optical transient detector (OTD) indicate that both the ICEFLUX and ECMWF schemes simulate the spatial distribution of lightning more accurately on a global scale than the CTH scheme does. The modified ECMWF scheme showed the highest prediction accuracy for the global distribution of lightning. Validation by atmospheric tomography (ATom) aircraft observations and tropospheric monitoring instrument (TROPOMI) satellite observations shows that the ICEFLUX scheme reduced the model biases to a greater extent than the ECMWF schemes when compared using the CTH scheme. The effects of the newly introduced lightning schemes on the tropospheric chemical fields were evaluated by comparison with the CTH scheme. Although the newly implemented lightning schemes have a minor effect on the tropospheric mean oxidation capacity compared to the CTH scheme, they led to marked change of oxidation capacity in different regions of the troposphere. Long-term trend analyses of flash and surface temperatures predicted using CHASER (2001-2020) show that lightning schemes predicted an increasing trend of lightning, except for the ICEFLUX scheme, which predicted a decreasing trend of lightning. The global lightning rates of increase during 2001-2020 predicted by the $\mathrm{CTH}$ scheme were $17.86 \% /{ }^{\circ} \mathrm{C}$ and $2.60 \% /{ }^{\circ} \mathrm{C}$, respectively, with and without nudging, which are slightly beyond the range of an earlier study $\left(5 \% /{ }^{\circ} \mathrm{C}-16 \% /{ }^{\circ} \mathrm{C}\right)$. Furthermore, the ECMWF schemes predicted a larger increasing trend of lightning flash rates under global warming by a factor of 3 (modified ECMWF scheme) and 5 (original ECMWF scheme) compared to the CTH scheme without nudging. In conclusion, the two new lightning schemes improved global lightning prediction in the CHASER model. However, further research is needed to assess the reproductivity of long-term trends of lightning.
\end{abstract}

\section{Keywords}

lightning, lightning scheme, lightning $\mathrm{NO}_{\mathrm{x}}$, chemistry-climate model, lightning under climate change

\section{Introduction}

35 Reactive nitric oxide (NO) can be formed during lightning activities. Also, NO can be oxidized quickly to nitrogen dioxide $\left(\mathrm{NO}_{2}\right)$. An equilibrium between $\mathrm{NO}$ and $\mathrm{NO}_{2}$ can be reached during daytime. Those gases are known collectively as $\mathrm{NO}_{x}$ (Finney, 2014). Actually, $\mathrm{LNO}_{\mathrm{x}}$ is estimated as contributing approximately $10 \%$ of the global $\mathrm{NO}_{\mathrm{x}}$ source. Regarded as the most dominant $\mathrm{NO}_{\mathrm{x}}$ source in the upper troposphere (Schumann and Huntrieser, 2007; Finney et al., 2016a), $\mathrm{NO}_{\mathrm{x}}$ is associated with many chemical reactions in the atmosphere. Most importantly, NO reacts with peroxy radical to reproduce 
$\mathrm{OH}$ radical. Photochemical dissociation of $\mathrm{NO}_{2}$ engenders the production of ozone (Isaksen and Hov, 1987; Grewe, 2007). The primary oxidants in the atmosphere, which are $\mathrm{OH}$ radical and ozone, control the oxidation capacity of the atmosphere. Results of several studies have indicated that global-scale $\mathrm{LNO}_{\mathrm{x}}$ emissions are an important contributor to ozone and other trace gases, especially in the upper troposphere (Labrador et al., 2005; Wild, 2007; Liaskos et al., 2015). Consequently, $\mathrm{LNO}_{\mathrm{x}}$ influences atmospheric chemistry and global climate to a considerable degree (Schumann and Huntrieser, 2007; Murray, 2016; Finney et al., 2016b; Tost, 2017). However, large uncertainties remain in predicting lightning and $\mathrm{LNO}_{\mathrm{x}}$ in chemical climate models (Tost et al., 2007). Therefore, improving lightning prediction accuracy and quantifying $\mathrm{LNO}_{\mathrm{x}}$ in chemical climate models is crucially important for future atmospheric research.

Chemical climate models such as CHASER (MIROC) (Sudo et al., 2002; Sudo and Akimoto, 2007; Watanabe et al., 2011) and root mean square error (RMSE) compared to the spaceborne Lightning Imaging Sensor (LIS) and Optical Transient Detector (OTD) lightning observation data (Finney et al.,2014; Lopez 2016). A lightning scheme proposed by Finney (2014), which is based on upward cloud ice flux, has shown better spatial and temporal correlation coefficients and RMSEs than the cloud top height scheme compared against the LIS/OTD lightning observations. Another lightning scheme also showed more accurate lightning prediction than the cloud top height scheme, which is also adopted in the ECMWF forecasting system (Lopez, 2016). The two new lightning schemes described above have only been validated in a few chemical transport and climate models. The new lightning schemes must be validated and compared in more chemical transport and climate models, such as CHASER. To achieve better prediction accuracy for lightning and better quantification of $\mathrm{LNO}_{\mathrm{x}}$ in chemical climate models, comparing and optimizing the existing lightning schemes and validating them with various observation data are also important.

Lightning simulations are also fundamentally important in chemical climate model studies for predictions of atmospheric chemical fields and climate. Nevertheless, different lightning schemes respond very differently on decadal to multi-decadal time scales under global warming. Some lightning schemes such as those using cloud top height or convective available potential energy $(\mathrm{CPAE}) \times$ precipitation as a proxy for calculating lightning indicate that lightning increases concomitantly with increasing global average temperature. By contrast, other lightning schemes, such as those using convective mass flux or upward cloud ice flux as a proxy of lightning, indicate that lightning will decrease as the global average temperature increases (Clark et al., 2017; Finney et al., 2018). Several studies (Price and Rind 1994; Zeng et al., 2008; Jiang and Liao 2013; Banerjee et al., 2014; Krause et al., 2014; Clark et al., 2017) have found 5-16\% increases in lightning flashes per degree of increase in global mean surface temperatures with the lightning scheme based on cloud top height. Over the continental United States (CONUS), the CAPE $\times$ precipitation proxy predicted a $12 \pm 5 \%$ increase in the CONUS lightning flash rate per degree of global mean temperature increase (Romps et al., 2014). By contrast, Finney et al. (2018) found a $15 \%$ global mean lightning flash rate decrease with the lightning scheme based on upward cloud ice flux in 2100 under a strong global warming scenario. Furthermore, a 2.0\% decrease in global mean lightning flashes per degree of increase in the global mean surface temperature with the lightning scheme based on convective mass flux has been reported by Clark et al. (2017). Although it remains unclear which lightning scheme is best suited to predicting future lightning (Romps, 2019), comparing different lightning schemes in different chemical climate models is valuable for consideration of the sensitivity of lightning to global warming.

80

This study introduced two new lightning schemes into CHASER (MIROC). The first lightning scheme (Finney et al., 2014) is based on upward cloud ice flux. The second one (Lopez, 2016), also adopted in the ECMWF forecasting system, 
calculates lightning flash rates as a function of the frozen precipitation convective flux, CAPE, and convective cloud-base height. In the case of the second lightning scheme, by tuning the equations and adjustment factors based on a study reported by McCaul et al. (2009), a new modified version of the second lightning scheme was also tested for CHASER (MIROC). This study conducted detailed validation of lightning and $\mathrm{LNO}_{\mathrm{x}}$ by LIS/OTD lightning observations, NASA/ATom aircraft observations, and TROPOMI satellite observations. The effects of different lightning schemes on the atmospheric chemical fields were evaluated. Also, 20-year (2001-2020) long-term trend analyses of lightning densities and $\mathrm{LNO}_{\mathrm{x}}$ emissions simulated by different lightning schemes were conducted. Based on the results, the effects of $\mathrm{LNO}_{\mathrm{x}}$ emissions during 20012020 on tropospheric $\mathrm{NO}_{x}$ and $\mathrm{O}_{3}$ column trends were estimated and discussed.

Research methods, including the model description and experiment setup, are described in section 2. In section 3.1, validation of lightning schemes using LIS/OTD lightning observations is explained. In section 3.2, $\mathrm{LNO}_{\mathrm{x}}$ emission simulation by different lightning schemes is verified with aircraft and satellite measurements. Section 3.3 presents discussion of the effects of different lightning schemes on the atmospheric chemical fields. Long-term trends of lightning simulated by different lightning schemes are analyzed and discussed in section 3.4. Section 3.5 discussed how LNO $_{x}$ emissions (20012020) trends influence the tropospheric $\mathrm{NO}_{\mathrm{x}}$ and $\mathrm{O}_{3}$ column trends. Section 4 presents the conclusions obtained from this study.

\section{Method}

\subsection{Chemistry-climate model}

The model used for this study is the CHASER (MIROC) global chemical transport and climate model (Sudo et al., 2002; Sudo and Akimoto, 2007; Watanabe et al. 2011; Ha et al., 2021), which incorporates consideration of detailed chemical and transport processes in the troposphere and stratosphere. CHASER calculates the distributions of 94 chemical species and reflects the effects of 269 chemical reactions (58 photolytic, 190 kinetic, 21 heterogeneous). Its tropospheric chemistry incorporates consideration of Non-Methane Hydrocarbons (NMHC) oxidation and the fundamental chemical cycle of $\mathrm{O}_{\mathrm{x}}-$ $\mathrm{NO}_{x}-\mathrm{HO}_{\mathrm{x}}-\mathrm{CH}_{4}-\mathrm{CO}$. Its stratospheric chemistry simulates chlorine-containing and bromine-containing compounds, chlorofluorocarbons (CFCs), hydrofluorocarbons (HFCs), carbonyl sulfide (OCS), and $\mathrm{N}_{2} \mathrm{O}$. Furthermore, it simulates the formation of polar stratospheric clouds (PSCs) and heterogeneous reactions on their surfaces. CHASER is coupled to the MIROC AGCM ver. 5.0 (Watanabe et al., 2011). Grid-scale large-scale condensation and cumulus convection (ArakawaSchubert scheme) are used to simulate cloud/precipitation processes. Aerosol chemistry is coupled with the SPRINTARS aerosol model (Takemura et al., 2009), which is also based on MIROC.

For this study, horizontal resolution used is T42 $\left(2.8^{\circ} \times 2.8^{\circ}\right)$, with vertical resolution of $36 \sigma$-p hybrid levels from the surface to approximately $50 \mathrm{~km}$. The AGCM meteorological fields (u, v, T) simulated by MIROC were nudged towards the six-hourly NCEP FNL data (https://rda.ucar.edu/datasets/ds083.2/, last access: 6 December 2021). Anthropogenic precursor emissions such as $\mathrm{NO}_{x}, \mathrm{CO}, \mathrm{O}_{3}, \mathrm{SO}_{2}$, and VOCs were obtained from the HTAP-II inventory for 2008 (https://edgar.jrc.ec.europa.eu/dataset htap_v2, last access: 6 December 2021), with biomass burning emissions from MACC-GFAS (Inness et al., 2013).

\subsection{Lightning $\mathrm{NO}_{\mathrm{x}}$ emission scheme}

120 The lightning flash rate in CHASER is originally parameterized by cloud-top height (Price and Rind, 1992, 1993), with a "Cshaped" $\mathrm{NO}_{\mathrm{x}}$ vertical profile adopted (Pickering et al., 1998). The equations used to calculate the lightning flash rate by cloud-top height are 


$$
\begin{aligned}
& F_{l}=3.44 \times 10^{-5} H^{4.9} \\
& F_{o}=6.2 \times 10^{-4} H^{1.73}
\end{aligned}
$$

125 where $F$ represents the total flash frequency (fl. $\left.\min ^{-1}\right), H$ stands for the cloud-top height (km), and subscripts $l$ and $o$ respectively denote the land and ocean (Price and Rind, 1992).

For this study, two new lightning schemes are implemented into CHASER (MIROC). One is based on upward cloud ice flux. It calculates the lightning flash rate by the following equations, as described by Finney et al. (2014).

$f_{l}=6.58 \times 10^{-7} \phi_{\text {ice }}$

$f_{o}=9.08 \times 10^{-8} \phi_{\text {ice }}$

Therein, $f_{l}$ and $f_{o}$ respectively represent the flash density $\left(\mathrm{fl} . \mathrm{m}^{-2} \mathrm{~s}^{-1}\right)$ of land and ocean. Also, $\phi_{\text {ice }}$ is the upward cloud ice flux at $440 \mathrm{hPa}\left(\mathrm{kg}_{\text {ice }} \mathrm{m}_{\text {cloud }}^{-2} \mathrm{~s}^{-2}\right)$ as calculated using

$\phi_{\text {ice }}=\frac{q \times \Phi_{\text {mass }}}{c}$,

where $q$ denotes the specific cloud ice water content at $440 \mathrm{hPa}\left(\mathrm{kg}_{\mathrm{ice}} \mathrm{kg}_{\text {air }}^{-1}\right), \Phi_{\text {mass }}$ stands for the updraught mass flux at $440 \mathrm{hPa}\left(\mathrm{kg}_{\text {air }} \mathrm{m}_{\text {cell }}^{-2} \mathrm{~s}^{-1}\right)$, and $c$ represents the fractional cloud cover at $440 \mathrm{hPa}\left(\mathrm{m}_{\text {cloud }}^{2} \mathrm{~m}_{\text {cell }}^{-2}\right)$.

Another new lightning scheme, also adopted in the ECMWF forecasting system, calculates lightning flash rates as a function of the frozen precipitation convective flux, CAPE, and convective cloud-base height (Lopez, 2016) as

where $f_{T}$ is the total lightning flash density (fl. $\mathrm{km}^{-2}$ day $\left.{ }^{-1}\right), z_{\text {base }}$ is the convective cloud-base height in $\mathrm{km}, \alpha$ is a constant obtained after calibration against the OTD climatology, which is set to 95.58 in this study. CAPE is diagnosed from the following equation.

$C A P E=\int_{z_{L F C}}^{z_{W=0}} \max \left(g \frac{T_{v}^{u}-\overline{T_{v}}}{\overline{T_{v}}}, 0\right) d z$

145 In that equation, $g$ is the constant of gravity. Also, $T_{v}^{u}$ and $\overline{T_{v}}$ respectively denote the virtual temperatures in the updraft and the environment. The integral in equation (7) starts at the level of free convection $z_{L F C}$ and stops at the level at which negative buoyancy is found $(w=0)$. Quantity $Q_{R}$ is intended to represent the charging rate of collisions between graupel and other types of hydrometeors inside the charge separation region. It is empirically calculated as

$Q_{R}=\int_{z_{0}}^{z_{-25}} q_{\text {graup }}\left(q_{\text {cond }}+q_{\text {snow }}\right) \bar{\rho} d z$,

150 where $z_{0}$ and $z_{-25}$ signify the heights of the $0^{\circ}$ and $-25^{\circ} \mathrm{C}$ isotherms, and $q_{\text {cond }}$ denotes the mass mixing ratio of cumulus cloud liquid water $\left(\mathrm{kg} \mathrm{kg}^{-1}\right)$. The respective amounts of graupel $\left(q_{\text {graup }} ; \mathrm{kg} \mathrm{kg}^{-1}\right)$ and snow $\left(q_{\text {snow }} ; \mathrm{kg} \mathrm{kg}^{-1}\right)$ are computed from the following equations for each vertical level of the model.

$q_{\text {graup }}=\beta \frac{P_{f}}{\bar{\rho} V_{\text {graup }}}$

$q_{\text {snow }}=(1-\beta) \frac{P_{f}}{\bar{\rho} V_{\text {snow }}}$

155 In those equations, $P_{f}$ denotes the vertical profile of the frozen precipitation convective flux $\left(\mathrm{kg} \mathrm{m}^{-2} \mathrm{~s}^{-1}\right), \bar{\rho}$ stands for the environmental air density $\left(\mathrm{kg} \mathrm{m}^{-3}\right)$, and $V_{\text {graup }}$ and $V_{\text {snow }}$ respectively express the typical fall speeds for graupel and snow set to 3.0 and $0.5 \mathrm{~m} \mathrm{~s}^{-1}$. The dimensionless coefficient $\beta$ is set as 0.7 for land and 0.45 for ocean to account for the observed lower graupel contents over oceans.

160 For the original ECMWF scheme, by tuning the convective cloud-base height, the calculation equations, and the adjustment factors for land and ocean, the lightning prediction accuracy is improved further, as explained in Section 3.1. The modified ECMWF scheme simulates the lightning flash rate by the following equations. 
$f_{l}=\alpha_{l} Q_{R a} C A P E^{1.3}$

$f_{o}=\alpha_{o} Q_{R a} C A P E^{1.3}$

165 Therein, $f_{l}$ and $f_{o}$ respectively denote the total flash density of land and ocean. Also, $\alpha_{l}$ and $\alpha_{o}$ are constants obtained after calibration against LIS/OTD climatology, respectively, for land and ocean. For this study, $\alpha_{l}$ and $\alpha_{o}$ are set respectively to $2.36 \times 10^{-5}$ and $1.45 \times 10^{-6}$. Then $C A P E$ is computed in the same way as the original ECMWF scheme. In addition, $Q_{R a}$ is a proxy for the charging rate resulting from the collisions between graupel and hydrometeors of other types inside the charge separation region (from $0^{\circ}$ to $-25^{\circ} \mathrm{C}$ isotherm), as reported by McCaul et al. (2009). Also, $Q_{R a}$ represents the total volumetric amount of precipitating ice in the charge separation region, calculated as

$Q_{R a}=\int_{z_{0}}^{z_{-25}}\left(q_{\text {graup }}+q_{\text {snow }}+q_{\text {ice }}\right) \bar{\rho} d z$,

where $z_{0}$ and $z_{-25}$ respectively stand for the heights of the $0^{\circ}$ and $-25^{\circ} \mathrm{C}$ isotherms, and $q_{\text {graup }}, q_{\text {snow }}$, and $q_{\text {ice }}$ respectively represent the mass mixing ratios of graupel, snow, and cloud ice. In this study, $q_{\text {graup }}$ and $q_{\text {snow }}$ were computed respectively by equations (9) and (10). For the modified ECMWF scheme, $V_{\text {graup }}$ and $V_{\text {snow }}$ are set respectively

to 3.1 and $0.5 \mathrm{~m} \mathrm{~s}^{-1}$. Then $q_{i c e}$ was diagnosed using Arakawa-Schubert cumulus parameterization.

\begin{tabular}{|c|c|c|}
\hline Abbreviation & Parameter & Remark \\
\hline $\begin{array}{c}\text { CTH } \\
\text { (Price, C., \& Rind, D., 1994) }\end{array}$ & Cloud top height & Originally used in CHASER (MIROC) \\
\hline $\begin{array}{c}\text { ICEFLUX } \\
\text { (Finney et al., 2014) }\end{array}$ & Upward cloud ice flux at $440 \mathrm{hPa}$ & $\begin{array}{l}\text { The } 440 \mathrm{hPa} \text { level is used as a pressure level representative of fluxes in } \\
\text { deep convective clouds }\end{array}$ \\
\hline $\begin{array}{l}\text { ECMWF-original } \\
\text { (Lopez, 2016) }\end{array}$ & $\begin{array}{l}\text { - } \text { CAPE } \\
\text { - } \text { Frozective cloud-brecipitation conveight } \\
\text { - Mixing ratio of cumulus cloud liquid water }\end{array}$ & Also adopted in the ECMWF forecasting system \\
\hline ECMWF-mod & $\begin{array}{l}\text { CAPE } \\
\text { - } \text { Mixing ratio of cumulus cloud ice } \\
\end{array}$ & $\begin{array}{l}\text { Equations and adjustment factors are modified from the original ECMWF } \\
\text { scheme. Equations are modified based on findings reported by McCaul } \\
\text { (McCaul Jr, E. W. et al., 2009) }\end{array}$ \\
\hline
\end{tabular}

Table 1 presents all the lightning schemes examined for this study. As described in this paper, the original ECMWF scheme and the modified ECMWF scheme are designated collectively as ECMWF schemes. The NO emission per flash used in CHASER for all the introduced lightning schemes was set to 111 moles NO per intra-cloud (IC) lightning flash and 1113 moles NO per cloud-to-ground (CG) lightning flash as parameters, as explained by Price et al. (1997). A fourth-order polynomial is used to calculate the proportion of total flashes that are cloud-to-ground $(p)$ based on the cold depth, as described in an earlier report (Price and Rind, 1993).

$p=\frac{1}{64.09-36.54 D+7.493 D^{2}-0.648 D^{3}+0.021 D^{4}}$.

185 In that equation, $D$ represents the cloud depth above $0^{\circ} \mathrm{C}$ in kilometres.

A "C-shaped" vertical profile for $\mathrm{LNO}_{\mathrm{x}}$ emission is used initially in CHASER (MIROC). However, a recent report of work by Ott et al. (2010) indicated that a "C-shaped" vertical profile of $\mathrm{LNO}_{x}$ might place too much mass near the surface and too little in the middle troposphere. A new $\mathrm{LNO}_{\mathrm{x}}$ vertical profile named the "backward C-shaped" profile was subsequently proposed by Ott et al. (2010). It was tested in this study using CHASER (MIROC).

\subsection{Observation data for model evaluation}

\subsubsection{Lightning observations}

The LIS/OTD gridded climatology datasets are used for this study, consisting of climatologies of total lightning flash rates observed using the Lightning Imaging Sensor (LIS) and spaceborne Optical Transient Detector (OTD): OTD aboard the MicroLab-1 satellite and LIS aboard the Tropical Rainfall Measuring Mission (TRMM) satellite (Cecil et al., 2014). Both sensors detect lightning by monitoring pulses of illumination produced by lightning in the $777.4 \mathrm{~nm}$ atomic oxygen multiplet above background levels. Both sensors, in low earth orbit, view an earth location for about $3 \mathrm{~min}$ as OTD passes overhead or for $1.5 \mathrm{~min}$ as LIS passes overhead. Actually, OTD and LIS circle the globe 14 times a day and 16 times a day, respectively. 
OTD collected data between +75 and $-75^{\circ}$ latitude from May 1995 through March 2000, whereas LIS observed between +38 and $-38^{\circ}$ latitude from January 1998 through April 2015.

The product used throughout this paper is the LIS/OTD 2.5 Degree Low Resolution Time Series (LRTS). The LRTS includes the daily lightning flash rate on a 2.5 $5^{\circ}$ regular latitude-longitude grid from May 1995 through April 2015.

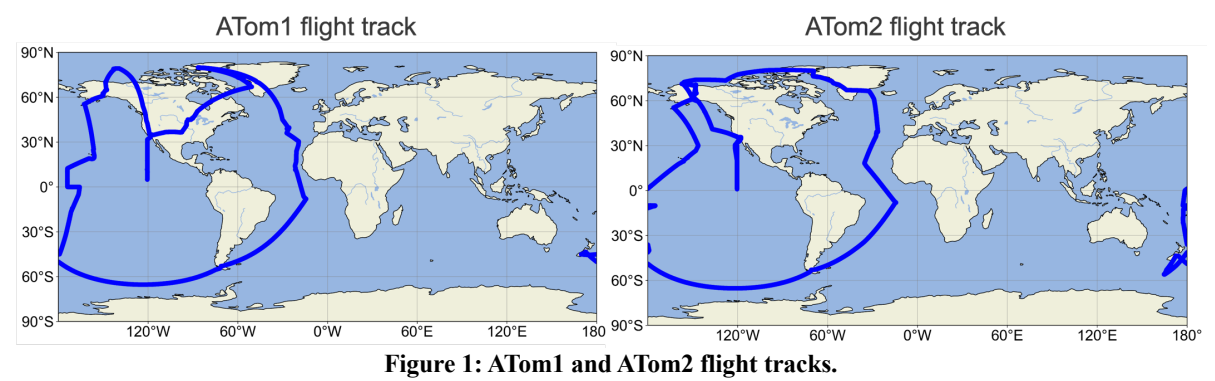

\subsubsection{Atmospheric tomography (ATom) aircraft observations}

To validate the $\mathrm{LNO}_{\mathrm{x}}$ emissions calculated by different lightning schemes, we used NO observation by the atmospheric tomography (ATom) aircraft missions (Wofsy et al., 2018). By deploying an extensive gas and aerosol payload on the NASA DC-8 aircraft, ATom is designed to sample the atmosphere systematically on a global scale, performing continuous profiling from 0.2 to $12 \mathrm{~km}$ altitude. Flights took place in each of the four seasons of 2016 through 2018 . To validate the $\mathrm{LNO}_{\mathrm{x}}$ emissions in different seasons, ATom1 (July-August 2016) and ATom2 (January-February 2017) were used for validation. Both ATom1 and ATom2 originate from the Armstrong Flight Research Center in Palmdale, California, USA, fly north to the western Arctic, south to the South Pacific, east to the Atlantic, north to Greenland, and return to California across central North America. Figure 1 exhibits the respective flight tracks of ATom1 and ATom2.

\subsubsection{TROPOMI satellite observations}

Tropospheric Monitoring Instrument (TROPOMI) is the payload on-board the Sentinel-5 Precursor (S5P) satellite of the European Space Agency (ESA), which was launched in October 2017. TROPOMI has been providing observations of important atmospheric pollutants $\left(\mathrm{NO}_{2}, \mathrm{O}_{3}, \mathrm{CO}, \mathrm{CH}_{4}, \mathrm{SO}_{2}, \mathrm{CH}_{2} \mathrm{O}\right)$ with an unprecedented horizontal resolution of approx. 7 $\times 3.5 \mathrm{~km}^{2}$ since August 2017 (changed to $5.5 \times 3.5 \mathrm{~km}^{2}$ after August 2019). For this study, the TROPOMI observations in 2019 for the $\mathrm{NO}_{2}$ tropospheric column were used to validate the $\mathrm{LNO}_{\mathrm{x}}$ emissions simulated by different lightning schemes.

\subsection{Experiment setup}

For this study, all the introduced lightning schemes were implemented into CHASER (MIROC). Six sets of experiments were conducted for this study, as presented in Table 2. For each set of experiments, the same initial conditions and chemical emissions were used except for $\mathrm{LNO}_{\mathrm{x}}$ emissions. The set of experiments that applied meteorological nudging also has the same meteorological conditions. The first set of experiments was conducted for the years of 2001-2020. It was used to validate the distribution of the lightning flash rate against LIS/OTD lightning observations and to derive the long-term lightning trend. The second set of experiments is the same as the first set of experiments, but using daily mean $\mathrm{LNO}_{\mathrm{x}}$ emission rates of 2001 calculated using lightning schemes for each year. This set of experiments is used to produce results for comparison with those of the first set of experiments to estimate the effects of $\mathrm{LNO}_{\mathrm{x}}$ emission trends on tropospheric $\mathrm{NO}_{\mathrm{x}}$ and $\mathrm{O}_{3}$ column trends. The third set of experiments gives results for 2011-2020. These experiments are used to estimate the effects of different lightning schemes on atmospheric chemical fields. To normalize the different annual $\mathrm{LNO}_{\mathrm{x}}$ emission amounts by different lightning schemes, the mean $\mathrm{LNO}_{x}$ production (2011-2020) of all lightning schemes was adjusted to 
5.0 $\mathrm{TgN} \mathrm{yr}^{-1}$ using different adjustment factors. The fourth set of experiments is for 2016, with the fifth set is for 2017. These two sets of experiments were conducted to compare model results with ATom1 and ATom2 aircraft observations. The sixth set of experiments is for 2019. It is conducted to validate model results using TROPOMI satellite observations.

Table 2: All experiments in this study

\begin{tabular}{ccccc}
\hline Number & Period & Nudging & LNOx emissions & Adjusted to 5.0 $\mathrm{TgN} \mathrm{yr}^{-1}$ \\
\hline \multirow{2}{*}{ 1st } & $2001-2020$ & On & Interactively calculated & No \\
& $2001-2020$ & Off & Interactively calculated & No \\
\hline \multirow{2}{*}{ 2nd } & $2001-2020$ & On & Fixed to 2001 & No \\
& $2001-2020$ & Off & Fixed to 2001 & No \\
\hline 3rd & $2011-2020$ & On & Interactively calculated & Yes \\
\hline 4th & 2016 & On & Interactively calculated & Yes \\
\hline 5th & 2017 & On & Interactively calculated & Yes \\
\hline 6th & 2019 & On & Interactively calculated & Yes \\
\hline
\end{tabular}

All experiments used the "backward C-shaped" $\mathrm{LNO}_{\mathrm{x}}$ vertical profile. The $\mathrm{NO}$ emissions per flash were set to 111 moles NO per IC (intro-cloud lightning flash) and 1113 moles NO per CG (cloud-to-ground lightning flash) as parameters drawn from work reported by Price et al. (1997).

\section{Results and Discussion}

\subsection{Validation of the lightning schemes}

To validate model results with lightning observation data in a broader range (between $+75^{\circ}$ and $-75^{\circ}$ latitude), lightning prediction accuracy for all introduced lightning schemes was compared with the climatological lightning distributions of OTD (1996-2000). Figure 2 presents a global map of the OTD annual mean lightning density spanning 1996-2000 and mean lightning density during 2007-2011, as simulated using different lightning schemes. Figure 3 displays a Taylor diagram, which presents the prediction accuracy of various lightning schemes in 2007-2011 simulations compared to the OTD 1996-2000 lightning climatology. Figure 2 shows that lightning over the ocean is not well reproduced by the original CTH scheme. Actually, it is improved considerably by the new lightning schemes. Compared with the CTH scheme, the original ECMWF scheme better represents the lightning distribution in South Asia including the Indian region. The ECMWF schemes and the ICEFLUX scheme reduced negative biases in North America compared to the CTH scheme. In Australia, the ECMWF schemes better simulate the horizontal distribution of lightning. All lightning schemes failed to capture the worldwide maximum value found over the Congo Basin, although all lightning schemes captured the active region in central Africa. 
https://doi.org/10.5194/gmd-2022-39

Preprint. Discussion started: 4 March 2022

(c) Author(s) 2022. CC BY 4.0 License.

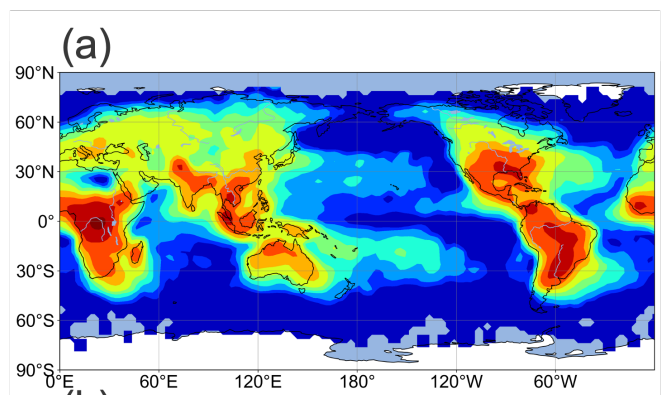

(b)

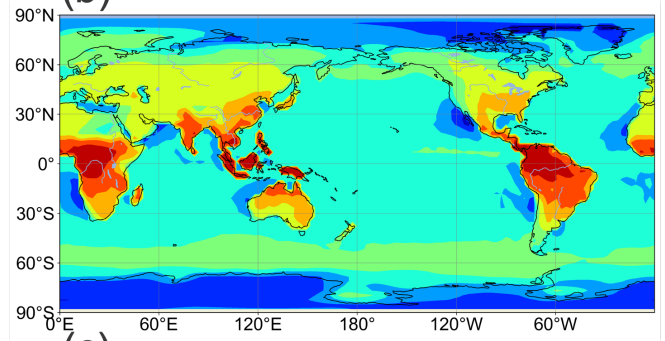

(c)

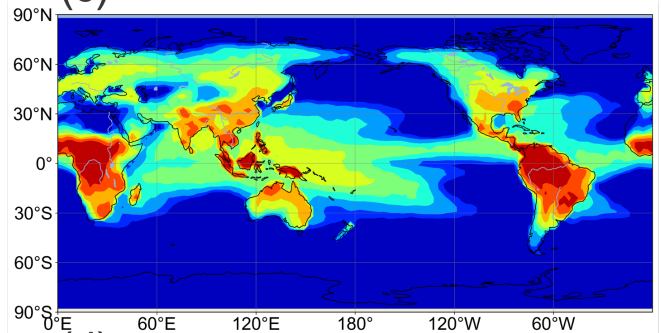

(d)

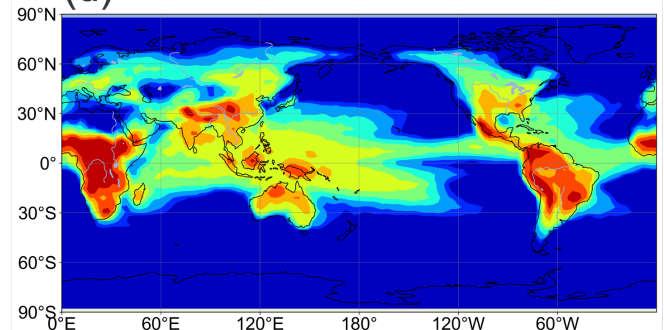

(e)

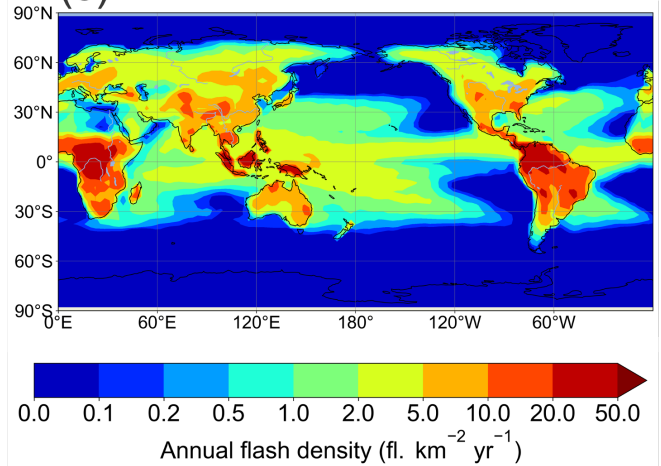
2007-2011, (c) the modified ECMWF scheme in 2007-2011, (d) the original ECMWF scheme in 2007-2011, and (e) the ICEFLUX scheme in 2007-2011. 
https://doi.org/10.5194/gmd-2022-39

Preprint. Discussion started: 4 March 2022

(c) Author(s) 2022. CC BY 4.0 License.

(c) (i)

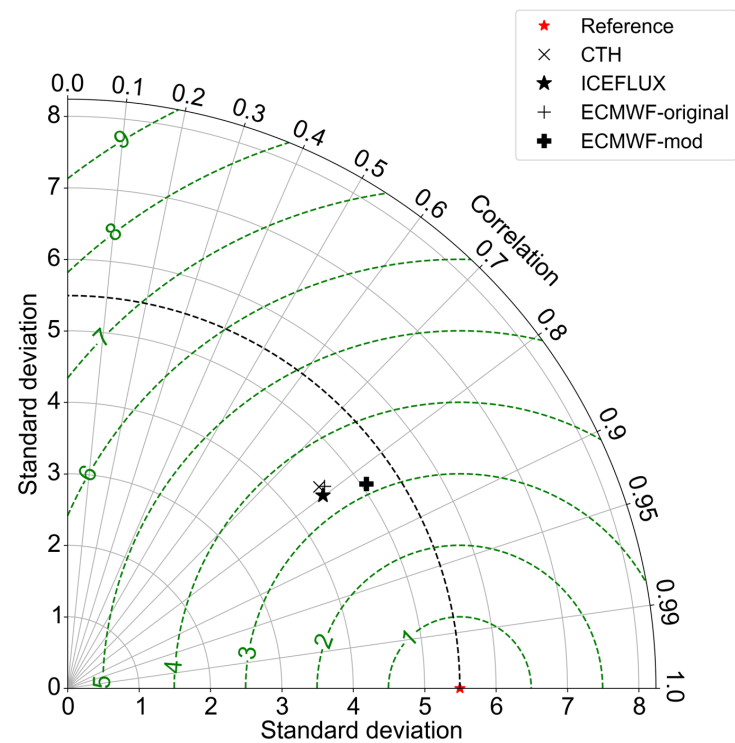

260 Figure 3: Taylor diagram showing the prediction accuracy of various lightning schemes in 2007-2011 simulations compared to the OTD 1996-2000 lightning climatology.

In Fig. 3, comparison of the annual mean lightning flash rate of OTD 1996-2000 and the CHASER calculation for 20072011 yields spatial correlation coefficients of 0.80 and 0.79 for the ICEFLUX and original ECMWF schemes, respectively,

265 which are slightly higher than that found for the CTH scheme (0.78). The RMSE of the ICEFLUX scheme is $3.31 \mathrm{fl}^{.} \mathrm{km}^{-2} \mathrm{yr}^{-}$ ${ }^{1}$, which is slightly less than that of the CTH scheme of $3.44 \mathrm{fl}^{\mathrm{km}} \mathrm{km}^{-2} \mathrm{yr}^{-1}$. Among all lightning schemes, the modified ECMWF scheme exhibits the highest spatial correlation coefficient $(0.83)$ and the lowest RMSE $\left(3.20 \mathrm{fl} . \mathrm{km}^{-2} \mathrm{yr}^{-1}\right)$. 

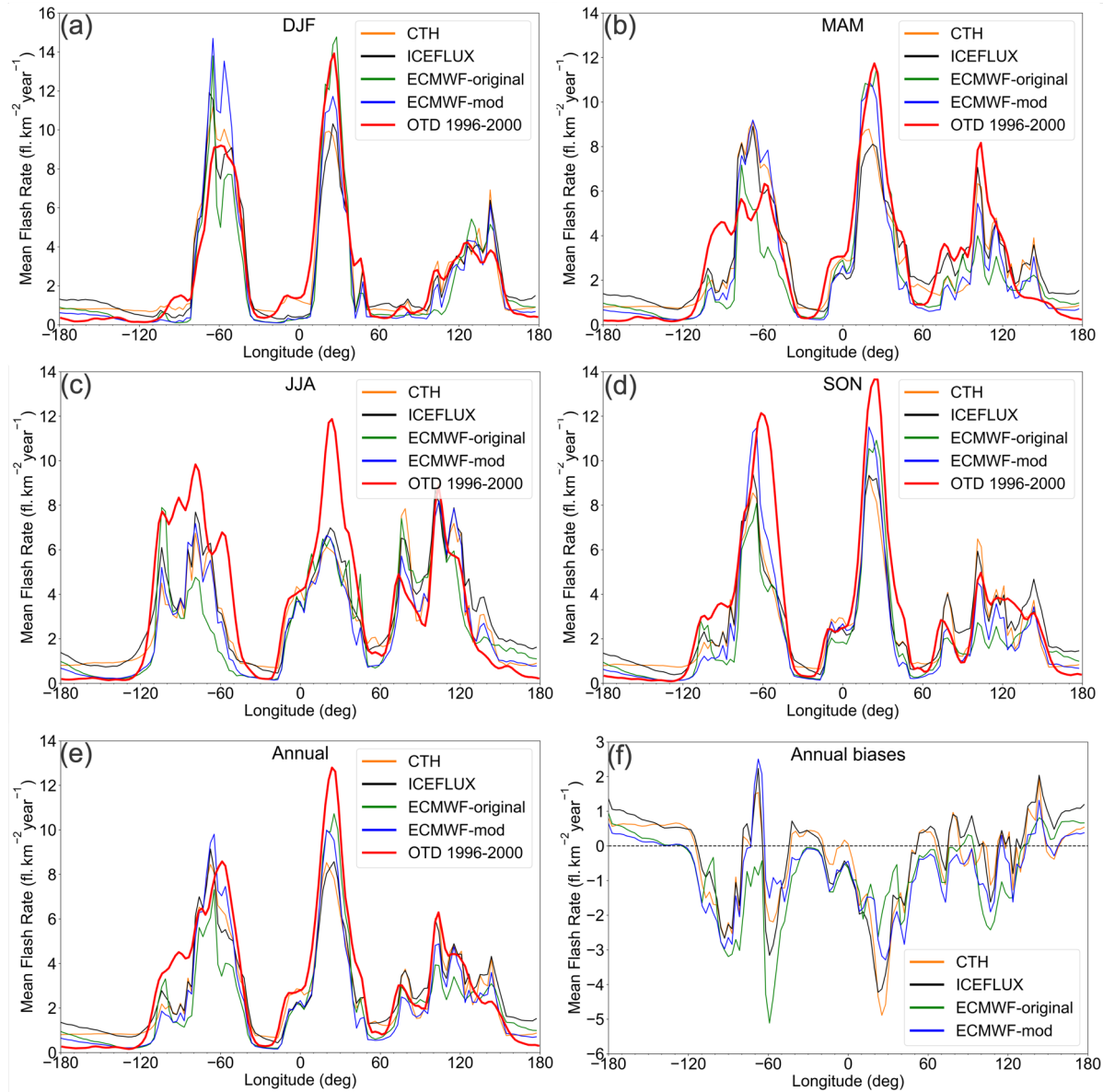

Figure 4: Seasonal and annual meridional average lightning flash densities distribution from OTD 1996-2000 climatology (red line) and from simulation results obtained using different lightning schemes. The meridional average is only taken within the OTD viewing region of $\pm 75^{\circ}$ latitude. The biases (model-obs.) in Fig. 4e are also portrayed in Fig. $4 \mathrm{f}$.

Figure 4 displays a comparison of seasonal and annual meridional average lightning flash densities from simulations (20072011) and OTD satellite observations (1996-2000). As Fig. 4 shows, the pairs of curves are usually in good agreement, even though the annual plot highlights the underestimation which occurs for Africa (from 0 degrees to 30 degrees east) and North America (from 80 degrees west to 120 degrees west). The ECMWF schemes have made improvements within Africa. Also, the ICEFLUX scheme has slightly reduced the biases over North America. A noticeable underestimation over the Americas in JJA and overestimation in MAM can be observed respectively in Figs. 4c and 4b. Lightning densities over Africa are underestimated to varying degrees in different seasons, with the greatest underestimation occurring in JJA (Fig. 4c).

Lightning densities over Asia (from 60 degrees east to 120 degrees east) are slightly underestimated in MAM (Fig. 4b). The ICEFLUX scheme has reduced the biases. 

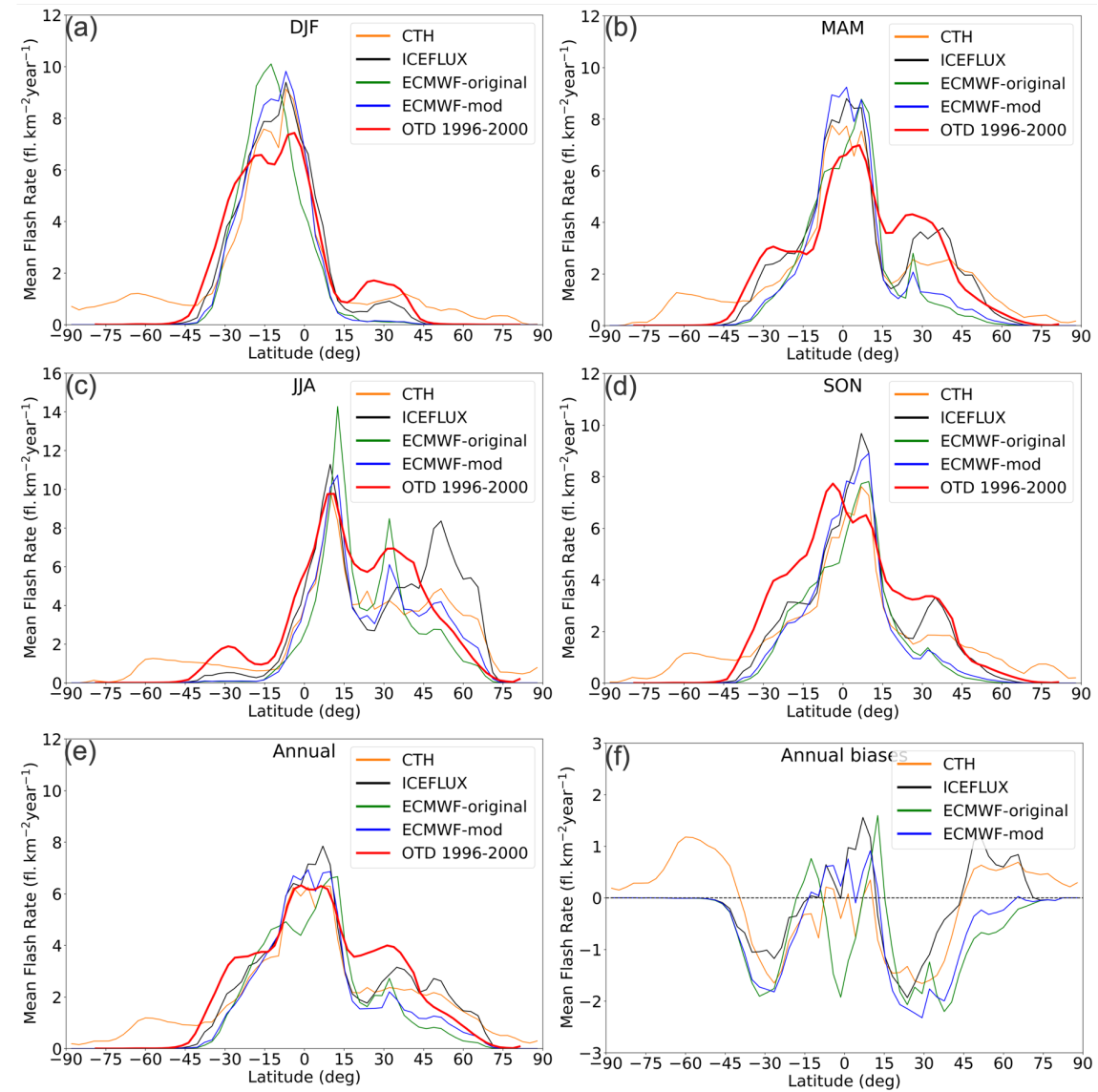

Figure 5: Seasonal and annual zonal average lightning flash densities distribution from OTD 1996-2000 climatology (red line) and $\mathbf{5 f}$.

Figure 5 is the same as Fig. 4, but for the zonal mean distributions. The curves of the model results and the observation results in Fig. 5 show good agreement. Figure 5 f shows that, overall, the ICEFLUX scheme and modified ECMWF scheme slightly overestimated the lightning densities near the equator $\left(5^{\circ} \mathrm{W}-5^{\circ} \mathrm{N}\right)$. All lightning schemes underestimated the lightning densities within $15^{\circ} \mathrm{N}-45^{\circ} \mathrm{N}$ and $15^{\circ} \mathrm{S}-45^{\circ} \mathrm{S}$. Figure $5 \mathrm{f}$ also shows that the ICEFLUX scheme has reduced the biases within $15^{\circ} \mathrm{N}-45^{\circ} \mathrm{N}$ and $15^{\circ} \mathrm{S}-45^{\circ} \mathrm{S}$. Furthermore, Fig. $5 \mathrm{f}$ shows that both the ICEFLUX scheme and the CTH scheme overestimated the flash densities within $45^{\circ} \mathrm{N}-90^{\circ} \mathrm{N}$. Only the CTH scheme overestimated the flash densities within $45^{\circ} \mathrm{S}-$ $90^{\circ} \mathrm{S}$. In DJF (Fig. 5a), all lightning schemes overestimated the flash densities over the low latitude region in the Southern Hemisphere. In MAM (Fig. 5b), lightning densities are overestimated near the equator and underestimated over $15^{\circ} \mathrm{N}-45^{\circ} \mathrm{N}$ and $15^{\circ} \mathrm{S}-45^{\circ} \mathrm{S}$ by all lightning schemes to varying degrees. In JJA (Fig. 5c), noticeable overestimation around $10^{\circ} \mathrm{N}$ by the original ECMWF scheme is apparent. Moreover, the CTH and the original ECMWF schemes respectively facilitated reduction of model biases over $15^{\circ} \mathrm{S}-45^{\circ} \mathrm{S}$ and $15^{\circ} \mathrm{N}-45^{\circ} \mathrm{N}$. Figure $5 \mathrm{c}$ also exhibits that the ICEFLUX scheme vastly overestimated the flash densities over $45^{\circ} \mathrm{N}-75^{\circ} \mathrm{N}$. As Fig. $5 \mathrm{~d}$ shows, the model-predicted lightning maximum value is shifted approximately 15 degrees to the north in SON compared to the lightning observations. Figure $5 \mathrm{~d}$ also shows that all lightning schemes underestimated the lightning densities over $15^{\circ} \mathrm{N}-45^{\circ} \mathrm{N}$. The ICEFLUX scheme has shown improvement over this region. 


\subsection{Validation of LNO $\mathrm{L}_{\mathrm{x}}$ emissions}

\subsubsection{Validation of $\mathrm{LNO}_{\mathrm{x}}$ emissions by ATom1 and ATom2 observations}

To verify the $\mathrm{LNO}_{x}$ emissions of different lightning schemes, we used ATom1 and ATom2 aircraft measurements (NO) for comparison against model results. All lightning schemes, when implemented in CHASER, produce flash rates corresponding to global annual $\mathrm{LNO}_{\mathrm{x}}$ emissions within the range estimated by Schumann and Huntrieser (2007) of 2-8 $\mathrm{TgN} \mathrm{yr}^{-1}$. To eliminate differences in annual total $\mathrm{LNO}_{\mathrm{x}}$ emissions by different lightning schemes, we chose to adjust the annual $\mathrm{LNO}_{\mathrm{x}}$ emissions of all lightning schemes to $5.0 \mathrm{TgN} \mathrm{yr}^{-1}$ by applying adjustment factors. The "backward C-shaped" $\mathrm{LNO}_{\mathrm{x}}$ vertical profile is applied to all lightning schemes.

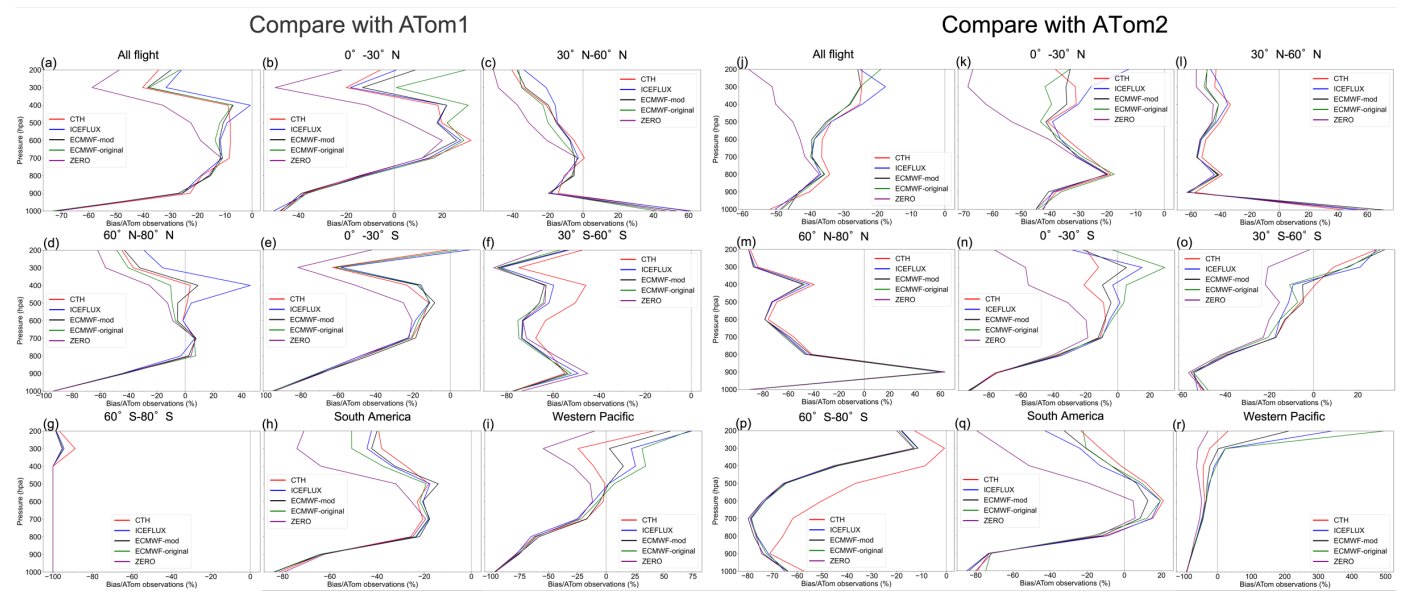

Figure 6: Vertical profile of biases/ATom1 observations $(a-i)$ and the vertical profile of biases/ATom2 observations $(j-r)$. The bias is the model bias against ATom observations. Data for each pressure level $P$ are calculated within the range of $P \pm 50 \mathrm{hPa}$. South America is the region of $0^{\circ}-30^{\circ} \mathrm{S}, 0^{\circ}-30^{\circ} \mathrm{W}$. The Western Pacific is the region of $10^{\circ} \mathrm{N}-30^{\circ} \mathrm{S}, 160^{\circ} \mathrm{E}-160^{\circ} \mathrm{W}$.

315 Table 3: Model biases when compared against ATom1 (upper panel) and ATom2 (lower panel). The unit is ppt. The biases within the South America region $\left(0-30^{\circ} \mathrm{S}, 0-30^{\circ} \mathrm{W}\right)$ and Western Pacific region $\left(10^{\circ} \mathrm{N}-30^{\circ} \mathrm{S}, 160^{\circ} \mathrm{E}-160^{\circ} \mathrm{W}\right)$ are also shown in this table.

\begin{tabular}{|c|c|c|c|c|c|c|c|c|c|}
\hline Lightning scheme & All flight & $0^{\circ}-30^{\circ} \mathrm{N}$ & $30^{\circ} \mathrm{N}-60^{\circ} \mathrm{N}$ & $60^{\circ} \mathrm{N}-80^{\circ} \mathrm{N}$ & $0^{\circ}-30^{\circ} \mathrm{S}$ & $30^{\circ} \mathrm{S}-60^{\circ} \mathrm{S}$ & $60^{\circ} \mathrm{S}-80^{\circ} \mathrm{S}$ & $\begin{array}{l}\text { South } \\
\text { America }\end{array}$ & $\begin{array}{c}\text { Western } \\
\text { Pacific }\end{array}$ \\
\hline СТH & -13.71 & -3.56 & -15.20 & -25.93 & -11.24 & -15.34 & -8.06 & -8.09 & -5.26 \\
\hline ECMWF-mod & -13.06 & -0.95 & -14.79 & -24.86 & -10.57 & -17.03 & -8.31 & -8.42 & -3.20 \\
\hline ECMWF-original & -12.63 & 3.90 & -15.19 & -27.55 & -10.62 & -17.17 & -8.31 & -9.89 & -1.27 \\
\hline $\mathrm{CTH}$ & -6.95 & -8.49 & -9.06 & -9.46 & -9.72 & 1.25 & -3.01 & -13.53 & -8.29 \\
\hline ICEFLUX & -6.49 & -6.38 & -9.16 & -9.71 & -9.87 & 2.32 & -5.39 & -24.59 & 0.94 \\
\hline ECMWF-mod & -7.15 & -8.74 & -9.95 & -9.69 & -8.93 & 2.06 & -5.47 & -19.02 & -2.92 \\
\hline
\end{tabular}

Table 3 presents model biases of different lightning schemes against the ATom1 and ATom 2 observations. Figure 6 displays the vertical profile of biases/ATom observations in percentage terms. In Table 3 and Fig. 6, case ZERO is the case with the lightning flash, with $\mathrm{LNO}_{\mathrm{x}}$ emissions completely switched off. Comparisons between model results and ATom observations were conducted within two specific regions (South America region and Western Pacific region) in which $\mathrm{LNO}_{\mathrm{x}}$ is the major source of $\mathrm{NO}_{x}$ (Fig. 7). From comparison of the results simulated using the CTH scheme with the "C-shaped" or the "backward C-shaped" $\mathrm{LNO}_{\mathrm{x}}$ vertical profile against ATom measurements, we found that the total model biases were slightly 
reduced by application of the "backward C-shaped" $\mathrm{LNO}_{\mathrm{x}}$ vertical profile compared to the "C-shaped" $\mathrm{LNO}_{\mathrm{x}}$ vertical profile.

As Table 3 and Fig. 6 show, the model generally tends to underestimate the NO concentrations. The model biases are reduced considerably by including lightning $\mathrm{NO}_{\mathrm{x}}$ sources. For ATom1, overall, the ICEFLUX scheme has the smallest model bias. The ECMWF schemes also reduced the model biases compared to the CTH scheme (Table 3). In the range of $30^{\circ} \mathrm{S}$ to $80^{\circ} \mathrm{N}$ in ATom 1 , the ICEFLUX scheme reduced the model biases considerably. Also, the ECMWF schemes slightly reduced the model biases compared to the $\mathrm{CTH}$ scheme (Table 3, Figs. 6a-e). However, in the range of $30^{\circ} \mathrm{S}-80^{\circ} \mathrm{S}$, the model biases were slightly extended by the ICEFLUX and the ECMWF schemes compared to the CTH scheme (Table 3 , Figs. $6 \mathrm{f}-\mathrm{g}$ ). This finding is consistent with Fig. 5c, in which the lightning densities predicted by the CTH scheme are larger than other lightning schemes in the Southern Hemisphere in JJA. For ATom2, overall, the ICEFLUX scheme and the original ECMWF scheme slightly reduced the model biases over the upper troposphere, compared to the CTH scheme (Fig. $6 \mathrm{j})$. The model biases were reduced by the ICEFLUX scheme over the low latitude region but were extended over the middle-latitude to the high-latitude region compared to the CTH scheme (Figs. 6k-p). The model biases were mostly reduced or extended over the middle to upper troposphere (Fig. 6). This is true because most $\mathrm{LNO}_{\mathrm{x}}$ was distributed over the middle to upper troposphere. Also, $\mathrm{NO}_{\mathrm{x}}$ has a longer lifetime over the middle to upper troposphere. In the Western Pacific region, results obtained from comparisons with ATom1 and ATom2 indicate that the CTH scheme underestimated, and the other schemes overestimated $\mathrm{LNO}_{\mathrm{x}}$ emissions in the upper troposphere; also, both the ICEFLUX scheme and ECMWF schemes reduced the total model biases considerably more than the CTH scheme did.

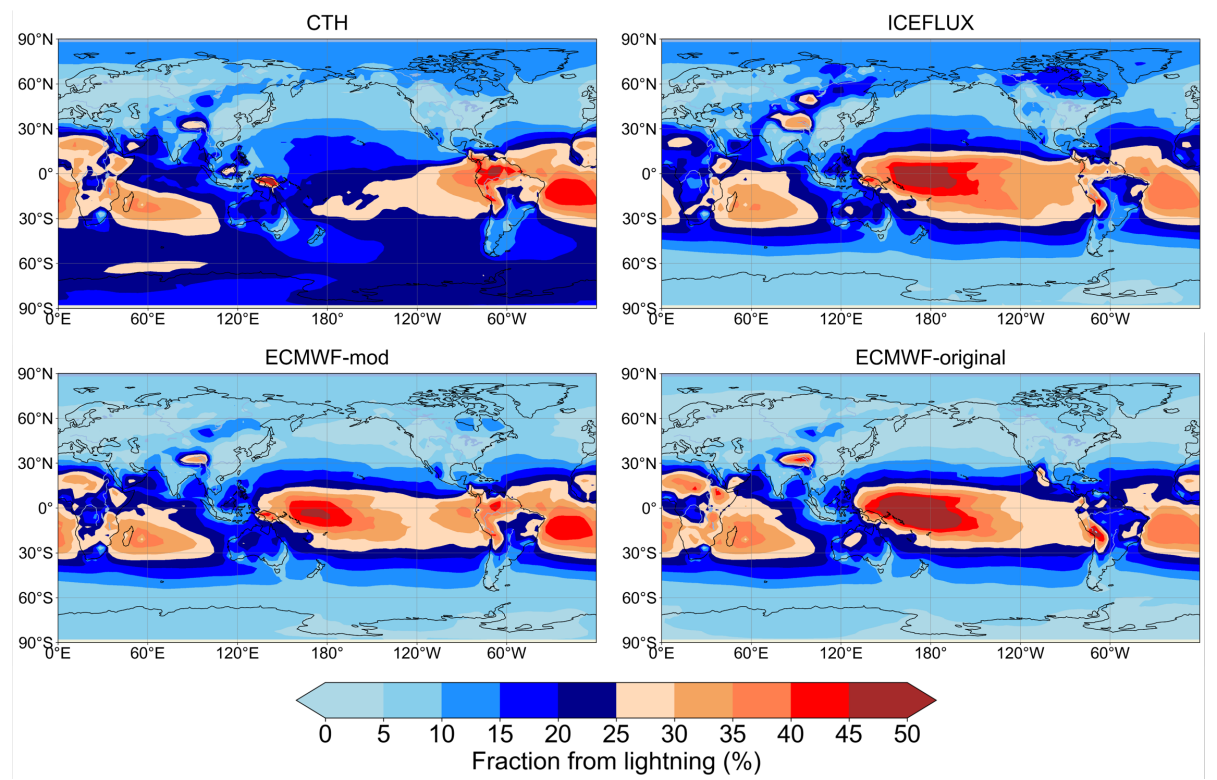

Figure 7: Sensitivity of simulated tropospheric $\mathrm{NO}_{2}$ columns to $\mathrm{LNO}_{\mathbf{x}}$ emissions using different lightning schemes. $\mathrm{NO}_{2}$ column because of $\mathrm{LNO}_{\mathrm{x}}$ emissions was determined as the difference between the simulation with $\mathrm{LNO}_{\mathrm{x}}$ emissions and a simulation that excludes $\mathrm{LNO}_{\mathrm{x}}$ emissions.

\subsubsection{Validation of LNO $_{x}$ emissions by TROPOMI satellite observations}

TROPOMI satellite observations of $\mathrm{NO}_{2}$ tropospheric columns were used to verify $\mathrm{LNO}_{\mathrm{x}}$ emission results obtained using the CHASER model. To eliminate differences in annual total $\mathrm{LNO}_{\mathrm{x}}$ emissions attributable to the different lightning schemes, we adjusted the annual $\mathrm{LNO}_{\mathrm{x}}$ emissions of all lightning schemes to $5.0 \mathrm{TgN} \mathrm{yr}^{-1}$ using different adjustment factors. For direct comparison between CHASER and TROPOMI $\mathrm{NO}_{2}$ tropospheric columns, the averaging kernel information from TROPOMI observations was used. The averaging kernels were applied to CHASER outputs following Eq. (15). 
In that equation, $X_{\text {chaser }}$ represents the CHASER $\mathrm{NO}_{2}$ tropospheric column after averaging kernels applied, $A_{\text {tropomi }}$ denotes the TROPOMI averaging kernels, $x_{\text {chaser }}$ denotes the $\mathrm{CHASER} \mathrm{NO}_{2}$ partial column at layer $\mathrm{i}$, and $\mathrm{N}$ denotes the number of tropospheric layers.

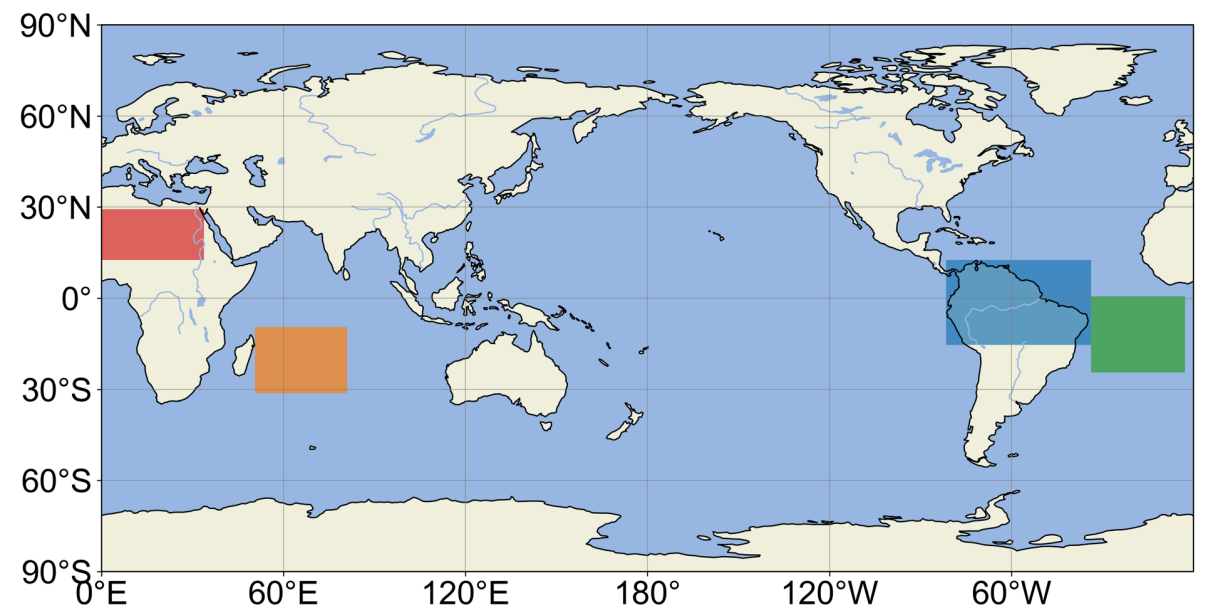

Figure 8: Four target regions for which $\mathrm{LNO}_{\mathrm{x}}$ is the major source of $\mathrm{NO}_{\mathrm{x}}$. The four target regions are North Africa (red), Indian Ocean (yellow), Amazon (blue), and South Atlantic (green).
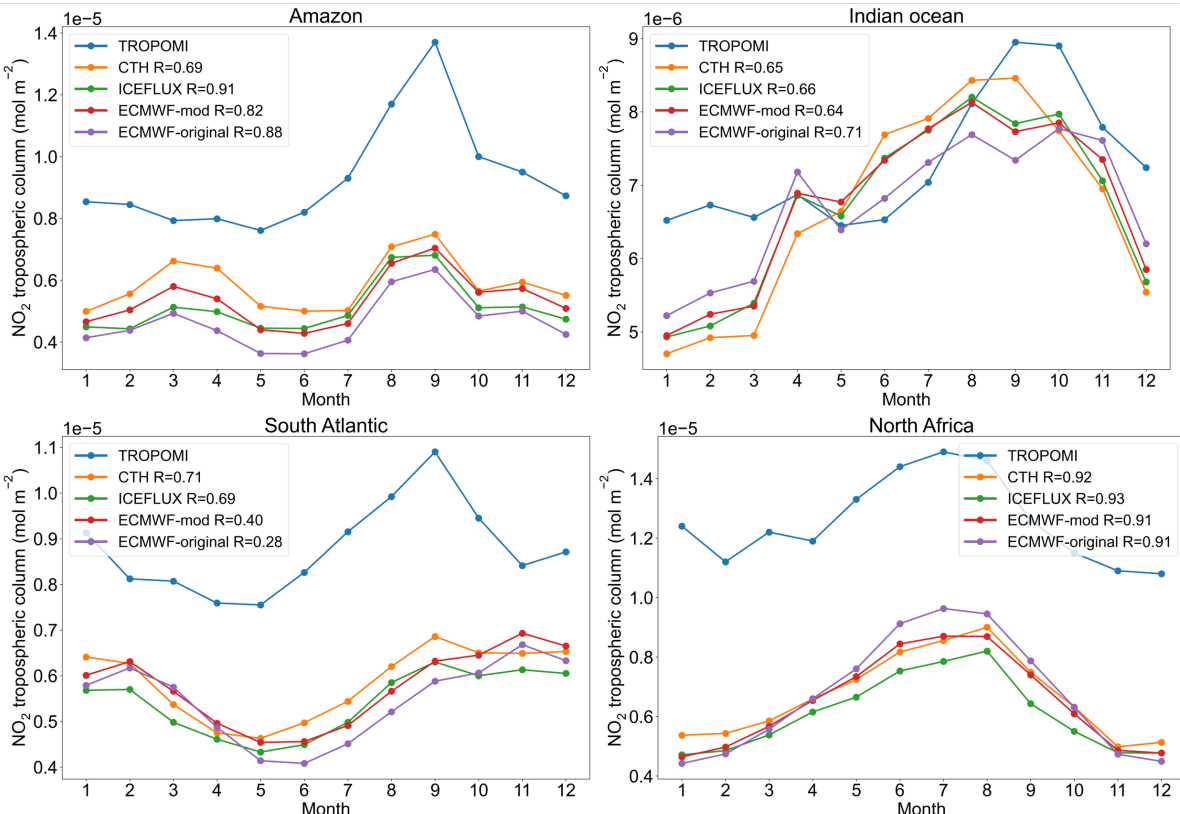

Figure 9: Comparisons of smoothed CHASER and TROPOMI (blue) $\mathrm{NO}_{2}$ tropospheric columns over four target regions in 2019. Legends show the temporal correlation coefficients.

Comparison between TROPOMI observations and CHASER outputs indicates that the CHASER model tends to underestimate $\mathrm{NO}_{2}$ tropospheric columns. Overall, the ICEFLUX scheme has shown the smallest model bias of $\mathrm{NO}_{2}$ tropospheric columns. To validate the results further and to compare the $\mathrm{LNO}_{\mathrm{x}}$ emissions of different lightning schemes by TROPOMI observations, four regions are chosen as target regions (Fig. 8), where $\mathrm{LNO}_{\mathrm{x}}$ is the major source of $\mathrm{NO}_{\mathrm{x}}$. Figure 7 shows the sensitivity of tropospheric $\mathrm{NO}_{2}$ columns to $\mathrm{LNO}_{x}$ emissions as simulated using different lightning schemes. As 
Fig. 7 shows, the four regions presented in Fig. 8 are hotspots for $\mathrm{LNO}_{\mathrm{x}}$ emissions. Therefore, these four regions are chosen as the target regions. Figure 9 presents a comparison of smoothed CHASER and TROPOMI $\mathrm{NO}_{2}$ tropospheric columns over four target regions in 2019. The spatial average values of each month in 2019 are shown in Fig. 9. That figure shows, generally, the model captured the temporal variation of $\mathrm{NO}_{2}$ tropospheric columns, especially in the land region (Amazon and North Africa). The ICEFLUX scheme showed good temporal correlation in all four regions, with improved temporal correlation coefficients for three of them (Amazon, Indian Ocean, North Africa) compared to the CTH scheme. The ECMWF schemes have similar temporal correlation coefficients to the CTH scheme in two target regions (Indian Ocean, North Africa). Compared with the CTH scheme, the ECMWF schemes improved the temporal correlation coefficients in the Amazon region considerably. However, the ECMWF schemes reduced the temporal correlation coefficients in the South Atlantic region, mainly because of inconsistency between the model and the observed trends during April-June.

\subsection{Effects of different lightning schemes on tropospheric chemical fields}

380 In the tropospheric chemical field, $\mathrm{LNO}_{\mathrm{x}}$ has an important role. The $\mathrm{LNO}_{\mathrm{x}}$ effects on the tropospheric chemical fields vary along with differences in the horizontal distribution of $\mathrm{LNO}_{\mathrm{x}}$ in different lightning schemes. To evaluate the influences of different lightning schemes on the tropospheric chemical fields, several ten-year (2011-2020) experiments were conducted with the ten-year mean $\mathrm{LNO}_{x}$ production of all lightning schemes adjusted to $5.0 \mathrm{TgN} \mathrm{yr}^{-1}$ (Section 2.4). CTH scheme with a "backward C-shaped" profile is regarded as the base scheme. The effects of different lightning schemes on the atmospheric chemistry are calculated as shown in Eq. (16).

Impact $_{i j}=\frac{\left(L S_{i j}-\text { Base }_{j}\right)}{\text { Base }_{j}}$

Therein, Impact ${ }_{i j}$ represents the effects of the $i$-th lightning scheme on the concentrations of target atmospheric component $j$. Also, $L S_{i j}$ denotes the concentrations of target atmospheric component $j$ simulated by the $i$-th lightning scheme. Base $e_{j}$ stands for the concentrations of target atmospheric component $j$ as simulated using the base scheme. 


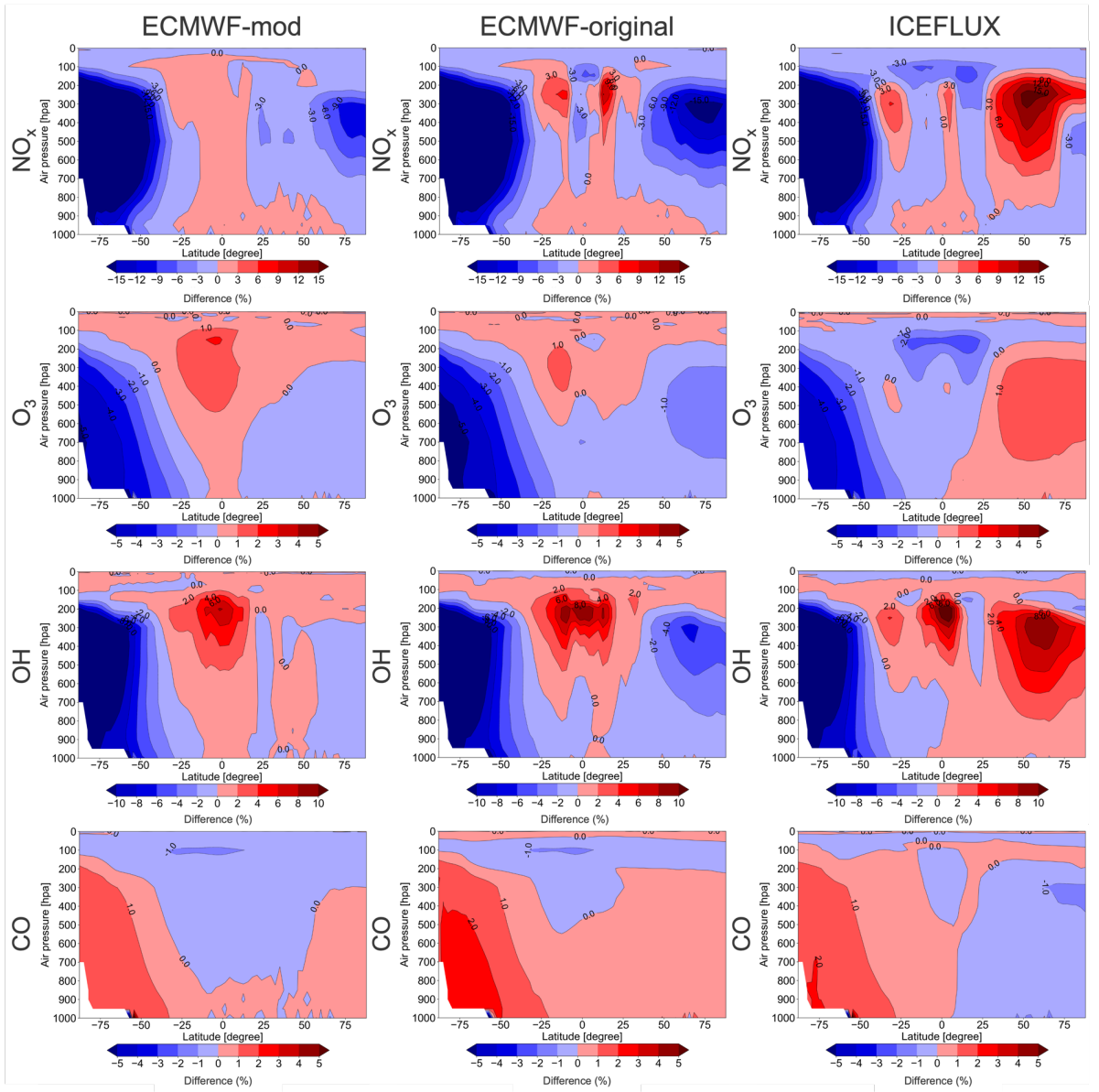

Figure 10: Effects of modified ECMWF scheme, original ECMWF scheme, and ICEFLUX scheme on the atmospheric chemical fields $\left(\mathrm{NO}_{\mathbf{x}}, \mathrm{O}_{3}, \mathrm{OH}, \mathrm{CO}\right)$ on the zonal mean $(\%)$.

Figure 10 presents the respective effects of the modified ECMWF, original ECMWF, and ICEFLUX schemes on the atmospheric chemical fields $\left(\mathrm{NO}_{\mathrm{x}}, \mathrm{O}_{3}, \mathrm{OH}, \mathrm{CO}\right)$ relative to the base scheme CTH. The modified ECMWF scheme led to an increase (approx. 3\%) in $\mathrm{NO}_{\mathrm{x}}$ concentration at low latitude regions and a decrease (approx. 15\%) at middle to high latitude regions. In the case of the modified ECMWF scheme, the concentration of ozone and $\mathrm{OH}$ radical mostly increased at low latitude regions and decreased at middle to high latitude regions in the Southern Hemisphere, which corresponds to the changing pattern of $\mathrm{NO}_{\mathrm{x}}$. Compared to the modified ECMWF scheme, the original ECMWF scheme caused a decrease rather than an increase in ozone and $\mathrm{OH}$ radical concentrations in the lower troposphere at low latitude regions. Unlike the modified ECMWF scheme, overall, the original ECMWF scheme led to an increase in CO. As Fig. 10 shows, the three lightning schemes led to a marked decrease in $\mathrm{NO}_{x}, \mathrm{O}_{3}$, and $\mathrm{OH}$ radical concentrations over the South Pole region. This decrease occurred because the lightning densities and the $\mathrm{LNO}_{\mathrm{x}}$ emissions simulated by the CTH scheme are markedly higher than those simulated using other lightning schemes at this latitude band (Fig. 2 and Fig. 5e). Moreover, $\mathrm{NO}_{\mathrm{x}}$ can engender the formation of ozone and $\mathrm{OH}$ radical. In the case of the ICEFLUX scheme, the concentrations of $\mathrm{NO}_{\mathrm{x}}$, ozone, and $\mathrm{OH}$ radical mostly increased in the Northern Hemisphere and decreased in the Southern Hemisphere.

Methane lifetime is an indicator reflecting the tropospheric oxidation capacity. The global mean tropospheric lifetime of 
CTH scheme, the original ECMWF scheme led to a slight increase in methane's global mean tropospheric lifetime. In contrast, the modified ECMWF and ICEFLUX schemes led to a slight decrease in methane's global mean tropospheric lifetime. Although little difference exists in the total tropospheric oxidation capacity simulated by different lightning

schemes, the ECMWF schemes and ICEFLUX scheme led to marked changes of oxidation capacity in different regions of the troposphere.

\subsection{Long-term trend analysis of lightning density}

The accuracy of predicting the simulated lightning distribution under the current climate is only one aspect of lightning scheme evaluation. The ability of the lightning scheme to reproduce the trend of lightning under climate change is also an important factor. For this study, 20 years of (2001-2020) experiments were conducted to analyze the long-term trends of lightning flash rates simulated using different lightning schemes (section 2.4).
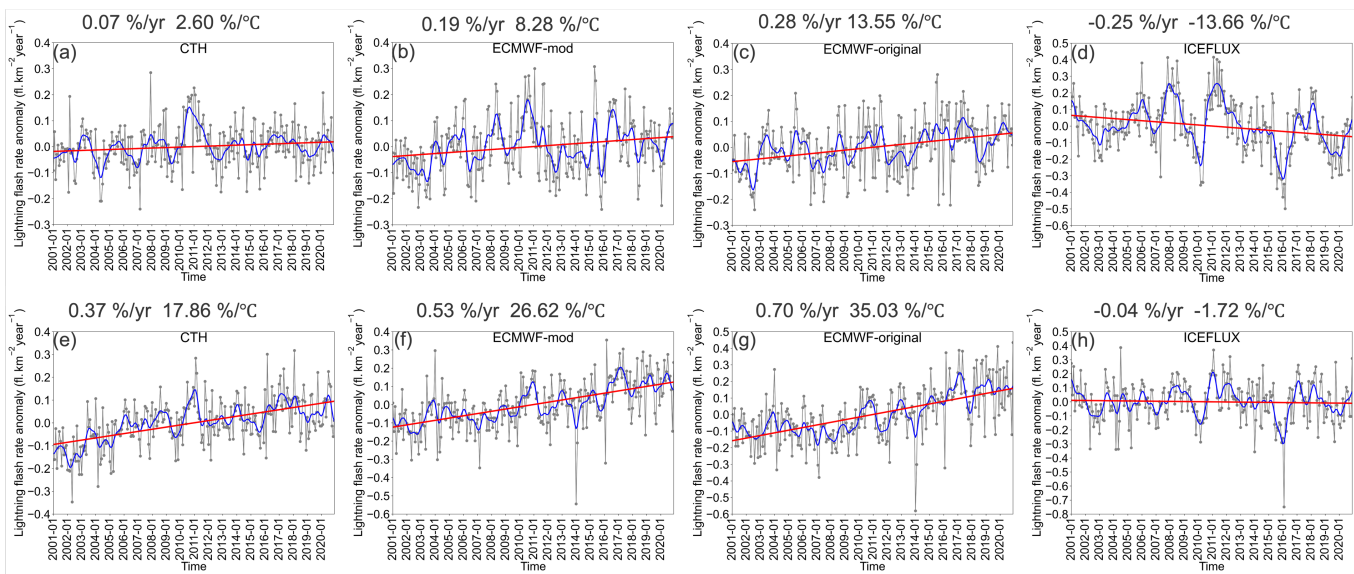

Figure 11: Global anomaly of lightning flash rates calculated from simulation results (2001-2020) using different lightning schemes. Figures 11(a-d) presents results without nudging; Figs. 11(e-h) presents results with nudging.

Table 4: Changes in global mean surface temperature ( $\Delta$ TS), global mean lightning flash rate $(\Delta L F R)$, and the rate of change of lightning flash rate corresponding to each degree Celsius increase in global mean surface temperature ( $\Delta$ LFR/ $\Delta$ TS). The upper panel shows results obtained without nudging. The lower panel presents results obtained with nudging. Changes were obtained by calculating the difference between the rightmost and leftmost points of the approximating curve for the 2001-2020 time-series data.

\begin{tabular}{cccc}
\hline Lightning scheme & $\Delta \mathrm{TS}\left({ }^{\circ} \mathrm{C}\right)$ & $\Delta \mathrm{LFR}(\%)$ & $\Delta \mathrm{LFR} / \Delta \mathrm{TS}\left(\% /{ }^{\circ} \mathrm{C}\right)$ \\
\hline CTH & 0.39 & 1.03 & 2.60 \\
ECMWF-mod & 0.37 & 3.08 & 8.28 \\
ECMWF-original & 0.41 & 5.50 & 13.55 \\
ICEFLUX & 0.38 & -5.18 & -13.66 \\
\hline Lightning scheme & $\Delta \mathrm{TS}\left({ }^{\circ} \mathrm{C}\right)$ & $\Delta \mathrm{LFR}(\%)$ & $\Delta \mathrm{LFR} / \Delta \mathrm{TS}\left(\% /{ }^{\circ} \mathrm{C}\right)$ \\
\hline CTH & 0.39 & 7.04 & 17.86 \\
ECMWF-mod & 0.39 & 10.49 & 26.62 \\
ECMWF-original & 0.39 & 13.77 & 35.03 \\
ICEFLUX & 0.39 & -0.68 & -1.72 \\
\hline
\end{tabular}

Figure 11 shows the global anomaly of lightning flash rates calculated from the simulation results. Because nudging to meteorological reanalysis data cannot be used when predicting lightning trends under future climate changes, we also showed the results without nudging. We used the Mann-Kendall rank statistic to ascertain whether the lightning trends in Fig. 11 are significant (Hussain et al., 2019). From results of the Mann-Kendall rank statistic test (significance set as 5\%), 

Fig. 11 shows, all lightning schemes predicted increasing trends of lightning except the ICEFLUX scheme, which predicted a decreasing lightning trend. These results are consistent with those of earlier studies (Price and Rind, 1994; Zeng et al., 2008; Jiang and Liao, 2013; Banerjee et al., 2014; Krause et al., 2014; Clark et al., 2017; Finney et al., 2018), which reported that the $\mathrm{CTH}$ scheme predicted a 5\%-16\% increase of lightning flashes per degree of increase in global mean surface temperatures and which reported that the ICEFLUX scheme predicted a 15\% decrease of total lightning flash rates in 2100 under Representative Concentration Pathway 8.5 (RCP8.5). The positive lightning trends are generally enhanced by application of meteorological nudging. Few studies have specifically examined the lightning trends predicted by the ECMWF schemes under global warming. When nudging was not applied, the ECMWF schemes predicted the increasing trends of lightning flash rates under global warming by factors of 3 (modified ECMWF scheme) and 5 (original ECMWF scheme) compared to the CTH scheme (Table 4).
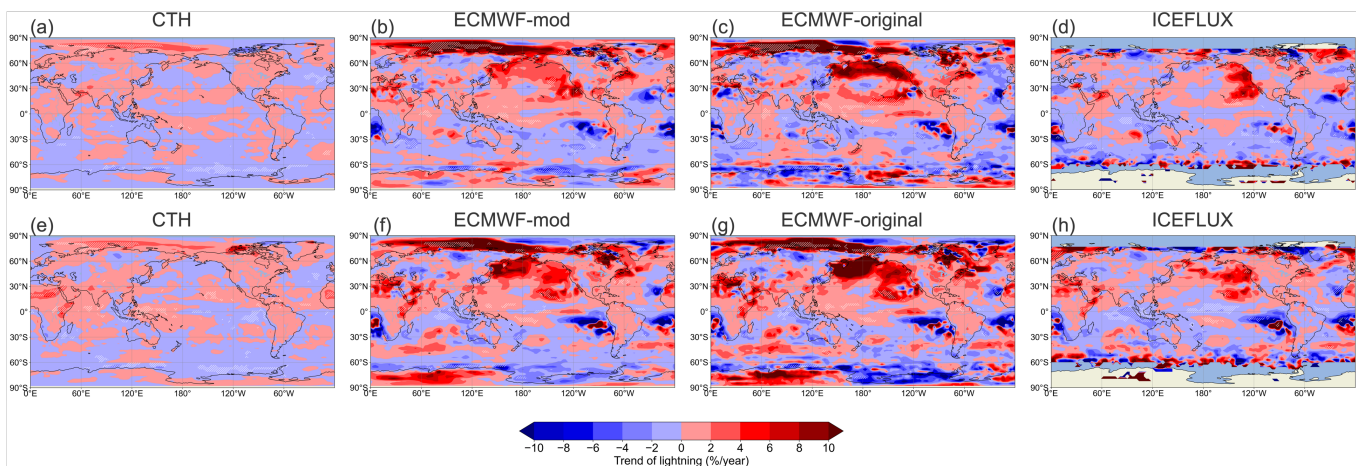

Figure 12: Changes in the lightning flash rate $\left(\% \mathrm{yr}^{-1}\right)$ during 2001-2020 on the two-dimensional map. Changes at every point were calculated from the function of approximating curve for the 2001-2020 time-series data at each grid cell. Figures 12(a-d) show results without nudging; Figs. 12(e-h) show results with nudging.

Figure 12 shows a global map of changes in the lightning flash rate $\left(\% \mathrm{yr}^{-1}\right)$ during $2001-2020$. In Fig. 12, the area in which the trend was found to be significant by the Mann-Kendall rank statistic test (significance level inferred for 5\%) is marked with hatched lines. As Fig. 12 shows, the distribution of trends simulated by the same lightning scheme is similar whether meteorological nudging was applied or not. As displayed in Fig. 12, in the Arctic region of the Eastern Hemisphere, both the CTH scheme and the ECMWF schemes showed an increasing trend of lightning. Earlier studies based on the World Wide Lightning Location Network (WWLLN) lightning observations have indicated that lightning densities in the Arctic increase concomitantly with increasing global mean surface temperature (Holzworth et al., 2021). Earlier studies indicate that the results of the CTH scheme and the ECMWF schemes are reasonable for the Arctic region of the Eastern Hemisphere. In the high latitude region of the Southern Hemisphere $\left(60^{\circ} \mathrm{S}-70^{\circ} \mathrm{S}\right)$, both the $\mathrm{CTH}$ scheme and the ECMWF schemes showed decreasing lightning trends. Lightning is rarely observed south of $60^{\circ} \mathrm{S}$ (Kelley, 2018). Moreover, the trends of lightning in this region expected to occur with global warming remain highly uncertain. In some parts of the Northern Pacific Ocean, the ECMWF schemes and ICEFLUX scheme results showed increasing trends of lightning, which is consistent results obtained from an earlier study (Walter and Buechler, 2008). All schemes show decreasing trends for lightning flash rates in Indonesia, although only the ICEFLUX scheme passed the significance test. In the North Atlantic, all schemes showed increasing lightning trends. Only the CTH scheme failed the significance test.

\subsection{Effects of $\mathrm{LNO}_{\mathrm{x}}$ emissions on trends of tropospheric $\mathrm{O}_{3}$ and $\mathrm{NO}_{\mathrm{x}}$ columns}

The long-term trends of lightning densities during 2001-2020 calculated using different lightning schemes have been discussed in section 3.4. Increasing or decreasing trends of lightning can engender corresponding trends of $\mathrm{LNO}_{\mathrm{x}}$ emissions, which can consequently influence trends of $\mathrm{NO}_{\mathrm{x}}$ and $\mathrm{O}_{3}$ concentrations. To ascertain the extent to which the $\mathrm{LNO}_{\mathrm{x}}$ emissions 

calculated $\mathrm{LNO}_{\mathrm{x}}$ emission rates, whereas the other one maintained the $2001 \mathrm{LNO}_{\mathrm{x}}$ emission rates for simulations of the entire 20 years. The $\mathrm{LNO}_{\mathrm{x}}$ emission effects on the trends of tropospheric $\mathrm{NO}_{\mathrm{x}}$ and $\mathrm{O}_{3}$ columns can be estimated quantitatively by comparing the results of these two sets of experiments.
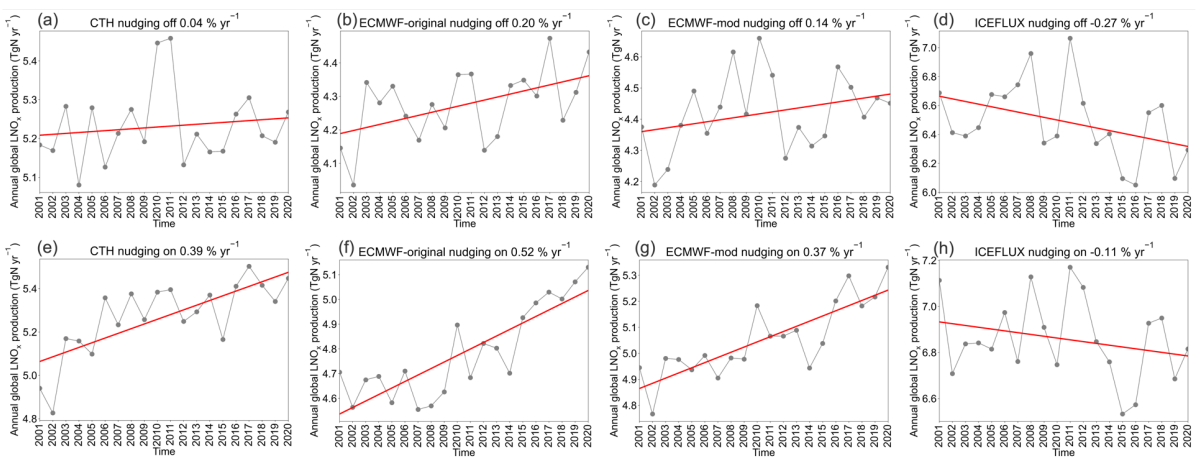

Figure 13: Trends of annual global $\mathrm{LNO}_{\mathrm{x}}$ emissions calculated from simulation results (2001-2020) from different lightning schemes. Red lines are fitting curves. Figures 13(a-d) present results without nudging; Figs. 13(e-h) present results with nudging. The number in the title of each figure represents the trend corresponding to that figure in the unit of $\% \mathrm{yr}^{-1}$.

Figure 13 presents trends of annual global $\mathrm{LNO}_{\mathrm{x}}$ emissions calculated from the simulation results (2001-2020) obtained using different lightning schemes. As Fig. 13 shows, the annual global $\mathrm{LNO}_{\mathrm{x}}$ emission trends correspond to the trends of lightning presented in Fig. 11. Similarly to the trends found for lightning, the trends of annual global $\mathrm{LNO}_{\mathrm{x}}$ emissions are also increased by application of meteorological nudging. Only the ICEFLUX scheme simulated decreasing trends of annual global $\mathrm{LNO}_{\mathrm{x}}$ emissions.

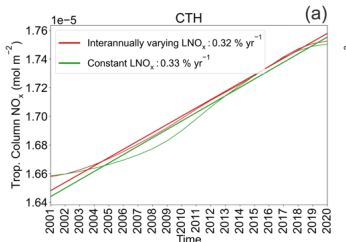

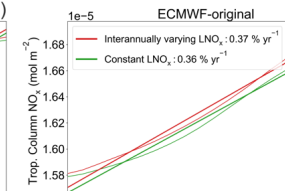
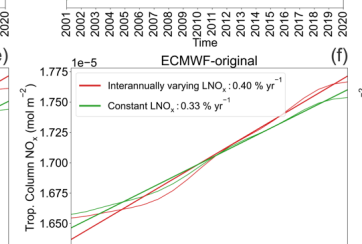

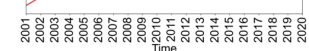

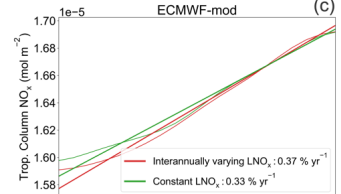

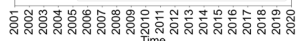

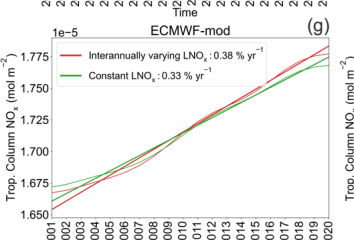

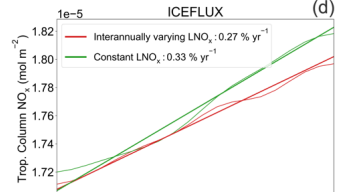

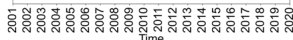

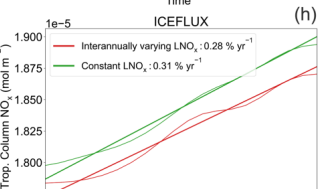

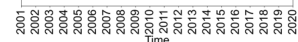

Figure 14: Trends of global mean tropospheric $\mathrm{NO}_{\mathrm{x}}$ columns calculated from simulation results (2001-2020) using different lightning schemes. Straight lines in the figure are the fitting curves. Straight lines and curves in red are results calculated using the first set of experiments. Straight lines and curves in green show results calculated using the second set of experiments (Table 2). The numbers in legends represent trends corresponding to that figure in the unit of $\% \mathrm{yr}^{-1}$. Figures 14(a-d) present results obtained without nudging; Figs. 14(e-h) present results obtained without nudging.

Figure 14 portrays trends of global mean tropospheric $\mathrm{NO}_{\mathrm{x}}$ columns calculated from the first and second set of experiments (Table 2). As Fig. 13 and Fig. 14 depict, when the trends of annual global $\mathrm{LNO}_{x}$ emissions are not strong (e.g., Fig. 13a), their effects on the trends of global mean tropospheric $\mathrm{NO}_{x}$ columns are negligible. The marked increasing trends of annual global $\mathrm{LNO}_{\mathrm{x}}$ emissions (Figs. 13e, $\mathrm{f}, \mathrm{g}$ ) led to great increases $(15.2 \%-21.2 \%)$ of the increasing trends of tropospheric $\mathrm{NO}_{\mathrm{x}}$ columns (Figs. 14e, f, g). In the case of ICEFLUX, because of the decreasing trends of $\mathrm{LNO}_{\mathrm{x}}$ emissions, the increasing trends of the tropospheric $\mathrm{NO}_{\mathrm{x}}$ columns decreased by around $10 \%$. 
https://doi.org/10.5194/gmd-2022-39

Preprint. Discussion started: 4 March 2022

(c) Author(s) 2022. CC BY 4.0 License.

(c) (1)
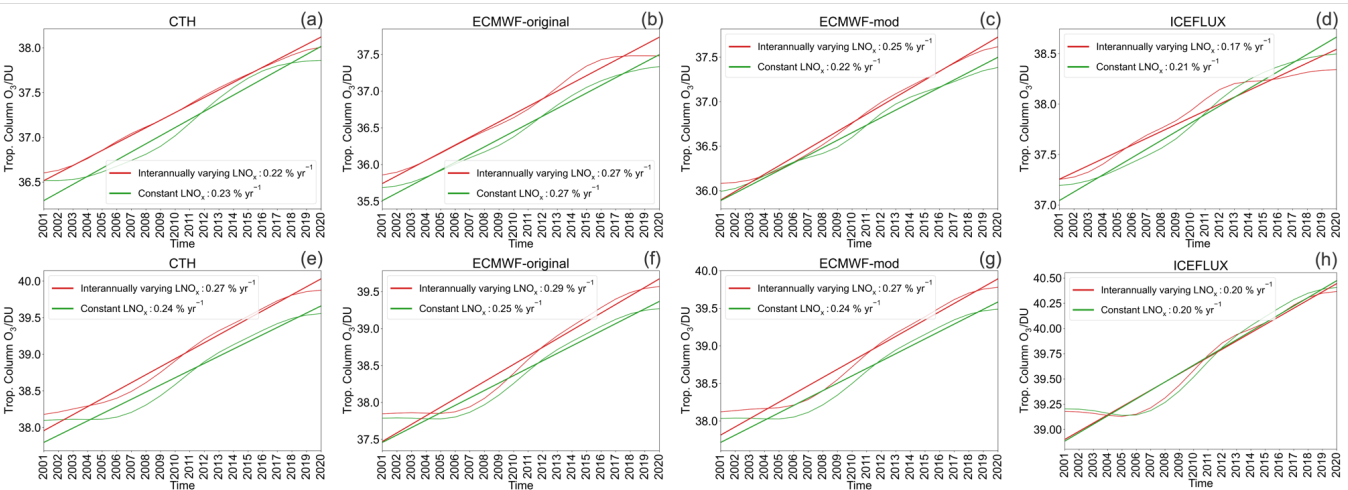

Figure 15: Trends of global mean tropospheric $\mathrm{O}_{3}$ columns calculated from simulation results (2001-2020) using different lightning . Straight lines in the figure are the fitting curves. Straight lines and curves in red are results calculated using the first set of experiments. Straight lines and curves in green are results calculated using the second set of experiments (Table 2). The number in the legend represents the trend corresponding to that figure in the unit of $\% \mathrm{yr}^{-1}$. Figures $15(\mathrm{a}-\mathrm{d})$ present results obtained without nudging; Figs. 15(e-h) show results obtained with nudging.

Figure 15 is similar to the results shown in Fig. 14, but for tropospheric $\mathrm{O}_{3}$ columns. Because $\mathrm{NO}_{\mathrm{x}}$ causes the formation of $\mathrm{O}_{3}$ by the fundamental chemical cycle of $\mathrm{O}_{\mathrm{x}}-\mathrm{NO}_{\mathrm{x}}-\mathrm{HO}_{\mathrm{x}}$, the trends of the global mean tropospheric $\mathrm{O}_{3}$ columns are affected strongly by trends of the global mean tropospheric $\mathrm{NO}_{\mathrm{x}}$ columns. For $\mathrm{CTH}$ and the original ECMWF schemes without nudging (Figs. 14a, b and Figs. 15a, b), the simulated trends of tropospheric $\mathrm{O}_{3}$ columns are almost identical because the trends of tropospheric $\mathrm{NO}_{x}$ columns simulated by the two sets of experiments are very similar. As Fig. 13 and Fig. 15 show,

510 the marked increasing trends of annual global $\mathrm{LNO}_{\mathrm{x}}$ emissions led to increases of the increasing trends of tropospheric $\mathrm{O}_{3}$ columns by around $15 \%$ (Figs. 15e, $\mathrm{f}, \mathrm{g}$ ). In the case of ICEFLUX without nudging, because of the decreasing trend of $\mathrm{LNO}_{\mathrm{x}}$ emissions, the increasing trend of the tropospheric $\mathrm{O}_{3}$ columns decreased by around $20 \%$ (Fig. 15d).
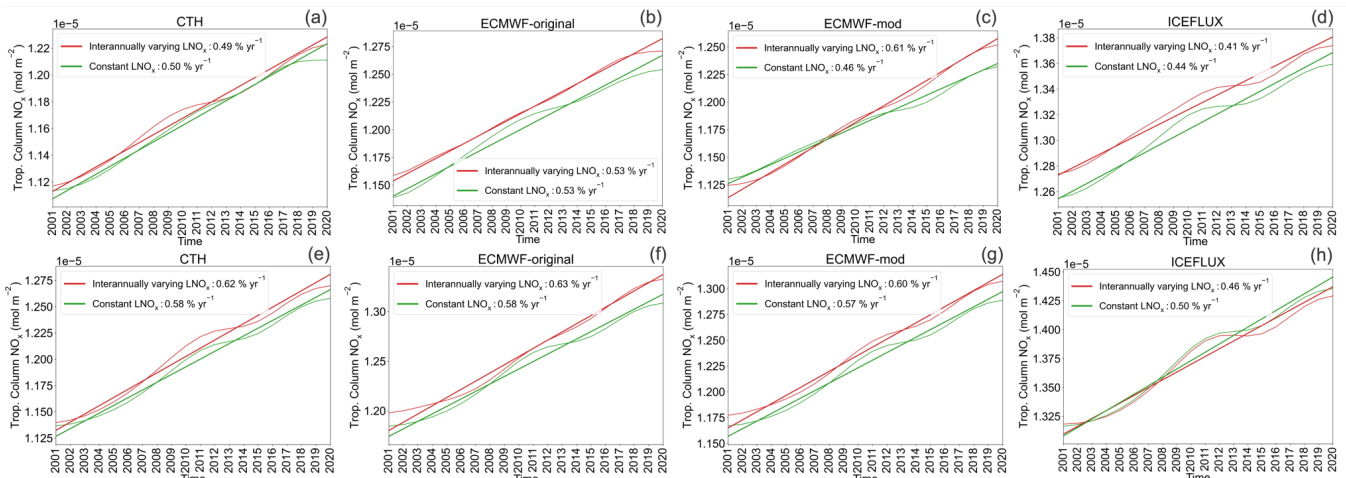

Figure 16: Trends of North Pacific region $\left(10^{\circ} \mathrm{S}-60^{\circ} \mathrm{N} ; 150^{\circ} \mathrm{E}-240^{\circ} \mathrm{E}\right)$ mean tropospheric $\mathrm{NO}_{\mathrm{x}}$ columns calculated from simulation

515 results (2001-2020) by different lightning schemes. Straight lines in the figure are the fitting curves. Straight lines and curves in red are results calculated using the first set of experiments. Straight lines and curves in green are results calculated using the second set of experiments (Table 2). The number in the legend represents the trend corresponding to that figure in the unit of \% $\mathrm{yr}^{-1}$. Figures 16(a-d) present results obtained without nudging; Figs. 16(e-h) present results obtained with nudging. 

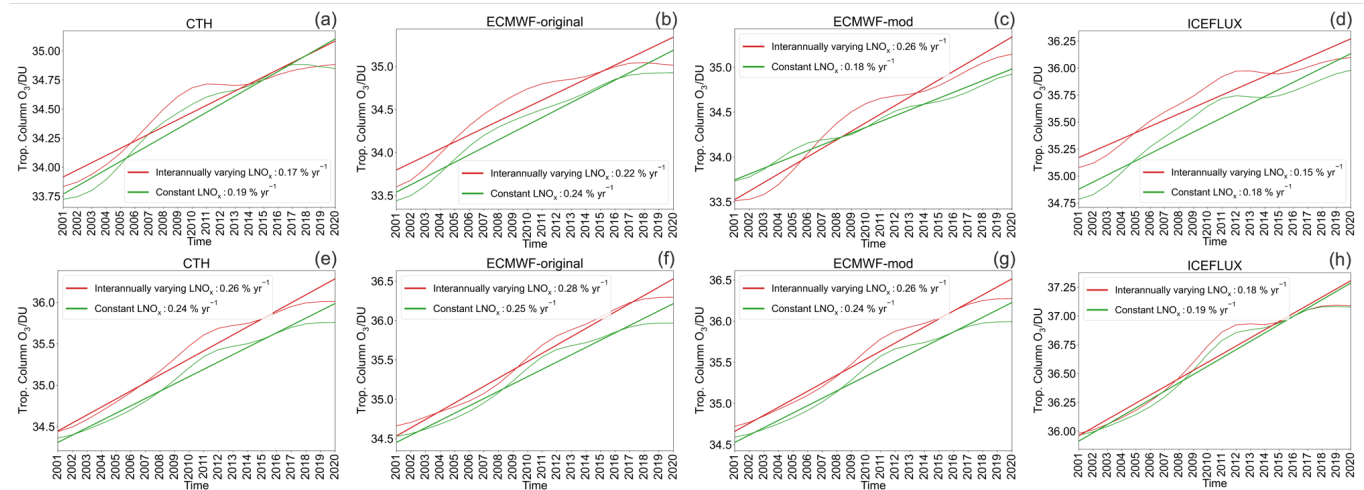

Figure 17: Trends of North Pacific region $\left(10^{\circ} \mathrm{S}-60^{\circ} \mathrm{N} ; 150^{\circ} \mathrm{E}-240^{\circ} \mathrm{E}\right)$ mean tropospheric $\mathrm{O}_{3}$ columns calculated from the simulation results (2001-2020) by different lightning schemes. Straight lines in the figure are the fitting curves. Straight lines and curves in red are the results calculated using the first set of experiments. Straight lines and curves in green are the results calculated using the second set of experiments (Table 2). The number in the legend represents the trend corresponding to that figure in the unit of \% $\mathrm{yr}^{-}$ ${ }^{1}$. Figures 17(a-d) show the results obtained without nudging; Figs. 17(e-h) show the results obtained with nudging.

As discussed in Section 3.4, lightning densities increased or decreased to a considerable degree in different regions of the world, as simulated by all the introduced lightning schemes (Fig. 12). We chose to investigate the $\mathrm{LNO}_{\mathrm{x}}$ emission effects on the tropospheric $\mathrm{NO}_{x}$ and $\mathrm{O}_{3}$ column trends over a region with greatly increasing $\mathrm{LNO}_{x}$, as simulated by the ECMWF schemes (North Pacific region $\left.10^{\circ} \mathrm{S}-60^{\circ} \mathrm{N} ; 150^{\circ} \mathrm{E}-240^{\circ} \mathrm{E}\right)$. Figure 16 shows trends of North Pacific region $\left(10^{\circ} \mathrm{S}-60^{\circ} \mathrm{N}\right.$; $150^{\circ} \mathrm{E}-240^{\circ} \mathrm{E}$ ) mean tropospheric $\mathrm{NO}_{\mathrm{x}}$ columns calculated from the first and second set of experiments (Table 2). Figure 17 is similar to the graphic presented in Fig. 16, but for tropospheric $\mathrm{O}_{3}$ columns. In the case of the modified ECMWF scheme without nudging (Fig. 16c and Fig. 17c), because of the increasing trend of $\mathrm{LNO}_{\mathrm{x}}$ emissions, the trends of tropospheric $\mathrm{NO}_{\mathrm{x}}$ and $\mathrm{O}_{3}$ columns increased significantly by $32.6 \%$ and $44.4 \%$, respectively. However, although the $\mathrm{LNO}_{\mathrm{x}}$ emissions increased significantly in the case of the original ECMWF scheme without nudging, the trends simulated by the first and second set of experiments are almost identical (Fig. 16b). This close approximation might be attributable to the different meteorological conditions and chemical fields during simulations.

In conclusion, because the ICEFLUX scheme predicts the opposite trends of $\mathrm{LNO}_{\mathrm{x}}$ emissions from the other lightning schemes, they simulate opposite effects on the long-term trends of global mean tropospheric $\mathrm{NO}_{x}$ and $\mathrm{O}_{3}$ columns.

Furthermore, an evident trend of annual global (regional) $\mathrm{LNO}_{\mathrm{x}}$ emissions has a strong effect on the trend of global (regional) mean tropospheric $\mathrm{NO}_{x}$ and $\mathrm{O}_{3}$ columns.

\section{Conclusions}

Two new lightning schemes, the ICEFLUX and the original ECMWF schemes, were implemented into CHASER (MIROC), a global chemical climate model. By modifying the equations and adjustment factors from the original ECMWF scheme based on work reported by McCaul et al. (2009), a new modified ECMWF scheme was also tested with CHASER (MIROC).

Using OTD lightning observations as validation data, both the ICEFLUX and ECMWF schemes simulated the spatial distribution of lightning more accurately on a global scale than the $\mathrm{CTH}$ scheme did, the lightning distribution in the ocean region was especially improved. The modified ECMWF scheme showed the highest prediction accuracy for the spatial distribution of lightning on a global scale. 
To verify the $\mathrm{LNO}_{\mathrm{x}}$ emissions of different lightning schemes, we used $\mathrm{NO}$ observations from ATom1 and ATom2. Overall, both the ICEFLUX scheme and the ECMWF schemes reduced the model biases compared to the CTH scheme, except in the case of comparison between the modified ECMWF scheme and ATom2 observations. Although both the ICEFLUX scheme and the ECMWF schemes reduced the model biases, the ICEFLUX scheme reduced the biases to a greater degree. Comparison of the model results with ATom1 observations revealed that the ICEFLUX scheme has the lowest model biases at $30^{\circ} \mathrm{S}-80^{\circ} \mathrm{N}$, whereas the $\mathrm{CTH}$ scheme has the lowest model biases at $30^{\circ} \mathrm{S}-80^{\circ} \mathrm{S}$. When comparing the model outputs with ATom 2 observations, the ICEFLUX scheme has the smallest model biases at low latitude region $\left(30^{\circ} \mathrm{S}-30^{\circ} \mathrm{N}\right)$. Results show that the $\mathrm{CTH}$ scheme has the smallest model biases at middle-latitude to high-latitude regions.

We also used TROPOMI $\mathrm{NO}_{2}$ tropospheric columns to verify the $\mathrm{LNO}_{\mathrm{x}}$ emissions of different lightning schemes. Compared with the CTH scheme, the ICEFLUX scheme reduced the global mean model bias, whereas the ECMWF schemes increased the global mean model bias, which indicates that the ICEFLUX scheme improved the $\mathrm{LNO}_{\mathrm{x}}$ simulation accuracy in the model. In the four target regions where $\mathrm{LNO}_{\mathrm{x}}$ is the dominant source of $\mathrm{NO}_{\mathrm{x}}$, the ICEFLUX scheme is the best lightning scheme able to capture the seasonal variation of $\mathrm{NO}_{2}$, whereas the ECMWF schemes only significantly improved the temporal correlations between the model and the TROPOMI observations in the Amazon region.

Effects of the newly implemented lightning schemes on the tropospheric chemical fields are evaluated compared to the CTH scheme. Compared with the CTH scheme, the ECMWF schemes mainly led to a slight increase in $\mathrm{NO}_{\mathrm{x}}$, ozone, and $\mathrm{OH}$ radical concentrations at low latitude regions and a decrease at middle-latitude to high-latitude regions. Effects of the ICEFLUX scheme on the tropospheric chemical fields differ from those of the ECMWF schemes. The ICEFLUX model mainly causes a slight increase of $\mathrm{NO}_{x}$, ozone, and $\mathrm{OH}$ radical concentrations in the Northern Hemisphere and a decrease in the concentrations of the three chemical species in the Southern Hemisphere. Commonality between the ECMWF schemes and the ICEFLUX scheme is that they both result in decreasing concentrations of $\mathrm{NO}_{x}$, ozone, and $\mathrm{OH}$ radical at the middle to high latitude regions of the Southern Hemisphere. Although the newly implemented lightning schemes have little effect on the total oxidation capacity of the troposphere compared to the CTH scheme, they led to marked change of oxidation capacity in different regions of the atmosphere.

This study also analyzed the long-term trends of lightning simulated by different lightning schemes under global warming during 2001-2020. All the lightning schemes predicted increasing lightning trends except the ICEFLUX scheme, which predicted a decreasing lightning trend. The Mann-Kendall rank statistic was used to ascertain whether the lightning trends were significant. Use of Mann-Kendall rank statistic tests revealed that all the lightning trends are significant, except the ICEFLUX scheme with nudging applied, for significance at 5\%. Moreover, findings showed that when nudging was not applied, the ECMWF schemes predicted an increasing trend of lightning flash rate under global warming by factors of 3 (modified ECMWF scheme) and 5 (original ECMWF scheme) compared to the CTH scheme.

Finally, we quantitatively estimated the $\mathrm{LNO}_{x}$ emission effects on tropospheric $\mathrm{NO}_{\mathrm{x}}$ and $\mathrm{O}_{3}$ column trends during 20012020. Results showed that a marked trend of annual global (regional) $\mathrm{LNO}_{\mathrm{x}}$ emissions significantly affects the trend of global (regional) mean tropospheric $\mathrm{NO}_{\mathrm{x}}$ and $\mathrm{O}_{3}$ columns.

In summary, comparison with results obtained using the CTH scheme demonstrated that both the ICEFLUX and ECMWF schemes improved the prediction accuracy of the lightning distribution on a global scale. In fact, the modified ECMWF scheme has the highest prediction accuracy. Using ATom aircraft observations and TROPOMI satellite observations to verify the $\mathrm{LNO}_{\mathrm{x}}$ emissions, the results show that, compared to the CTH scheme, the ICEFLUX scheme reduced the model 
595 biases to a greater degree than the ECMWF schemes. Although a considerable degree of uncertainty remains in the prediction of lightning trends under global warming, results of most studies have indicated that the global average lightning density can be expected to increase by about $10 \%$ for each degree of global warming (Betz et al., 2008, p. 521). This value is most consistent with the lightning increase rate predicted by the modified ECMWF scheme without nudging in this study. Future research should be undertaken for specific examination of development of lightning schemes that both accurately predict the global distribution of $\mathrm{LNO}_{\mathrm{x}}$ and which predict the changes in lightning that are expected to occur concomitantly with global climate change.

\section{Code availability}

The source code for CHASER to reproduce results in this work is obtainable from the repository at https://doi.org/10.5281/zenodo.5835796 (He et al., 2022)

\section{Data availability}

The LIS/OTD data used for this study are available from https://ghrc.nsstc.nasa.gov/hydro/?q=LRTS (last access: 11 January 2022). The ATom data used for this study are available from https://daac.ornl.gov/ATOM/guides/ATom_merge.html (last access: 11 January 2022). The TROPOMI data used for this study are available from https://s5phub.copernicus.eu/dhus/\#/home (last access: 11 January 2022).

\section{Author contribution}

YFH introduced new lightning schemes into CHASER (MIROC) by adding new codes to CHASER (MIROC), conducted all simulations, interpreted the results, and wrote the manuscript. KS developed the model code, conceived of the presented idea, and supervised the findings of this work and the manuscript preparation. HMSH provided the TROPOMI data and the relevant codes to pre-process the TROPOMI data.

\section{Competing interests}

The authors declare that they have no conflict of interest.

\section{Acknowledgements}

This research was supported by the Global Environment Research Fund (S-12 and S-20) of the Ministry of the Environment (MOE), Japan, and JSPS KAKENHI Grant Numbers: JP20H04320, JP19H05669, and JP19H04235. This work was

620 supported by Japan Science and Technology Agency (JST) Support for Pioneering Research Initiated by the Next Generation (SPRAING), Grant Number JPMJSP2125. The author (Initial) would like to take this opportunity to thank the "Interdisciplinary Frontier Next-Generation Researcher Program of the Tokai Higher Education and Research System." The simulations were completed with the supercomputer (NEC SX-Aurora TSUBASA) at NIES (Japan). Thanks to NASA scientists and staff for providing LIS/OTD lightning observation data

625 (https://ghrc.nsstc.nasa.gov/uso/ds_docs/lis_climatology/LISOTD_climatology_dataset.html, last access: 9 January 2022) and ATom data (https://espo.nasa.gov/atom/content/ATom, last access: 9 January 2022). We are grateful to ESA scientists and staff for providing TROPOMI data (http://www.tropomi.eu, last access: 9 January 2022). We thank Yannick Copin for software he developed to help us with the Taylor diagram.

\section{References}

630 Banerjee, A., Archibald, A. T., Maycock, A. C., Telford, P., Abraham, N. L., Yang, X., Braesicke, P., and Pyle, J. A.: Lightning $\mathrm{NO}_{x}$, a key chemistry-climate interaction: impacts of future climate change and consequences for tropospheric oxidising capacity, Atmos. Chem. Phys, 14, 9871-9881, https://doi.org/10.5194/acp-14-9871-2014, 2014. 
Betz, H. D., Schumann, U., and Laroche, P.: Lightning: Principles, instruments and applications: Review of modern lightning research, Springer Netherlands, 1-641 pp., https://doi.org/10.1007/978-1-4020-9079-0, 2009.

Cecil, D. J., Buechler, D. E., and Blakeslee, R. J.: Gridded lightning climatology from TRMM-LIS and OTD: Dataset description, Atmos. Res., 135-136, 404-414, https://doi.org/10.1016/j.atmosres.2012.06.028, 2014.

640 Clark, S. K., Ward, D. S., and Mahowald, N. M.: Parameterization-based uncertainty in future lightning flash density, Geophys. Res. Lett., 44, 2893-2901, https://doi.org/10.1002/2017GL073017, 2017.

Finney, D. L., Doherty, R. M., Wild, O., Huntrieser, H., Pumphrey, H. C., and Blyth, A. M.: Using cloud ice flux to parametrise large-scale lightning, Atmos. Chem. Phys., 14, 12665-12682, https://doi.org/10.5194/acp-14-12665-2014, 2014.

Finney, D. L., Doherty, R. M., Wild, O., Young, P. J., and Butler, A.: Response of lightning $\mathrm{NO}_{\mathrm{x}}$ emissions and ozone production to climate change: Insights from the Atmospheric Chemistry and Climate Model Intercomparison Project, Geophys. Res. Lett., 43, 5492-5500, https://doi.org/10.1002/2016GL068825, 2016a.

Finney, D. L., Doherty, R. M., Wild, O., and Abraham, N. L.: The impact of lightning on tropospheric ozone chemistry using a new global lightning parametrisation, Atmos. Chem. Phys., 16, 7507-7522, https://doi.org/10.5194/acp-16-7507-2016, $2016 b$.

Finney, D. L., Doherty, R. M., Wild, O., Stevenson, D. S., MacKenzie, I. A., and Blyth, A. M.: A projected decrease in lightning under climate change, Nat. Clim. Chang., 8, 210-213, https://doi.org/10.1038/s41558-018-0072-6, 2018.

Grewe, V.: Impact of climate variability on tropospheric ozone, Sci. Total Environ., 374, 167-181, https://doi.org/10.1016/j.scitotenv.2007.01.032, 2007.

Ha, P. T. M., Matsuda, R., Kanaya, Y., Taketani, F., and Sudo, K.: Effects of heterogeneous reactions on tropospheric chemistry: A global simulation with the chemistry-climate model CHASER V4.0, Geosci. Model Dev., 14, 3813-3841, https://doi.org/10.5194/gmd-14-3813-2021, 2021.

He, Y., Hoque, M. S. H., and Sudo, K.: Introducing new lightning schemes into the CHASER (MIROC) chemistry climate model [Code], Zenodo, https://doi.org/10.5281/ZENODO.5835796, 2022.

Holzworth, R. H., Brundell, J. B., McCarthy, M. P., Jacobson, A. R., Rodger, C. J., and Anderson, T. S.: Lightning in the Arctic, Geophys. Res. Lett., 48, e2020GL091366, https://doi.org/10.1029/2020GL091366, 2021.

Hui, J. and Hong, L.: Projected Changes in $\mathrm{NO}_{\mathrm{x}}$ Emissions from Lightning as a Result of 2000-2050 Climate Change, Atmos. Ocean. Sci. Lett., 6, 284-289, https://doi.org/10.3878/j.issn.1674-2834.13.0042, 2013.

Hussain, M. and Mahmud, I.: pyMannKendall: a python package for non parametric Mann Kendall family of trend tests., J. Open Source Softw., 4, 1556, https://doi.org/10.21105/joss.01556, 2019. 
Inness, A., Baier, F., Benedetti, A., Bouarar, I., Chabrillat, S., Clark, H., Clerbaux, C., Coheur, P., Engelen, R. J., Errera, Q., Flemming, J., George, M., Granier, C., Hadji-Lazaro, J., Huijnen, V., Hurtmans, D., Jones, L., Kaiser, J. W., Kapsomenakis, J., Lefever, K., Leitão, J., Razinger, M., Richter, A., Schultz, M. G., Simmons, A. J., Suttie, M., Stein, O., Thépaut, J.-N., Thouret, V., Vrekoussis, M., Zerefos, C., and the MACC team: The MACC reanalysis: an 8 yr data set of atmospheric composition, Atmos. Chem. Phys., 13, 4073-4109, https://doi.org/10.5194/acp-13-4073-2013, 2013.

Isaksen, I. S. A. and Hov, Ø.: Calculation of trends in the tropospheric concentration of $\mathrm{O}_{3}, \mathrm{OH}, \mathrm{CO}, \mathrm{CH}_{4}$ and $\mathrm{NO}_{\mathrm{x}}$, Tellus $\mathrm{B}$, 39 B, 271-285, https://doi.org/10.1111/j.1600-0889.1987.tb00099.x, 1987.

Kelley, O. A., Thomas, J. N., Solorzano, N. N., and Holzworth, R. H.: Fire and Ice: Intense covective precipitation observed at high latitudes by the GPM satellite's Dual-frequency Precipitation Radar (DPR) and the ground-based World Wide Lightning Location Network (WWLLN), AGU Poster, 2018, H43F-2487, 2018.

Krause, A., Kloster, S., Wilkenskjeld, S., and Paeth, H.: The sensitivity of global wildfires to simulated past, present, and future lightning frequency, J. Geophys. Res. Biogeosciences, 119, 312-322, https://doi.org/10.1002/2013JG002502, 2014.

Labrador, L. J., von Kuhlmann, R., and Lawrence, M. G.: The effects of lightning-produced $\mathrm{NO}_{\mathrm{x}}$ and its vertical distribution on atmospheric chemistry: sensitivity simulations with MATCH-MPIC, Atmos. Chem. Phys., 5, 1815-1834, https://doi.org/10.5194/acp-5-1815-2005, 2005.

695

Lamarque, J. F., Shindell, D. T., Josse, B., Young, P. J., Cionni, I., Eyring, V., Bergmann, D., Cameron-Smith, P., Collins, W. J., Doherty, R., Dalsoren, S., Faluvegi, G., Folberth, G., Ghan, S. J., Horowitz, L. W., Lee, Y. H., MacKenzie, I. A., Nagashima, T., Naik, V., Plummer, D., Righi, M., Rumbold, S. T., Schulz, M., Skeie, R. B., Stevenson, D. S., Strode, S., Sudo, K., Szopa, S., Voulgarakis, A., and Zeng, G.: The atmospheric chemistry and climate model intercomparison Project

700 (ACCMIP): Overview and description of models, simulations and climate diagnostics, Geosci. Model Dev., 6, 179-206, https://doi.org/10.5194/gmd-6-179-2013, 2013.

Liaskos, C. E., Allen, D. J., and Pickering, K. E.: Sensitivity of tropical tropospheric composition to lightning $\mathrm{NO}_{\mathrm{x}}$ production as determined by replay simulations with GEOS-5, J. Geophys. Res., 120, 8512-8534, https://doi.org/10.1002/2014JD022987, 2015.

Lopez, P.: A lightning parameterization for the ECMWF integrated forecasting system, Mon. Weather Rev., 144, 30573075, https://doi.org/10.1175/MWR-D-16-0026.1, 2016.

710 McCaul, E. W., Goodman, S. J., LaCasse, K. M., and Cecil, D. J.: Forecasting lightning threat using cloud-resolving model simulations, Weather Forecast., 24, 709-729, https://doi.org/10.1175/2008WAF2222152.1, 2009.

Murray, L. T.: Lightning NO $x$ and Impacts on Air Quality, https://doi.org/10.1007/s40726-016-0031-7, 25 April 2016.

715 Ott, L. E., Pickering, K. E., Stenchikov, G. L., Allen, D. J., DeCaria, A. J., Ridley, B., Lin, R. F., Lang, S., and Tao, W. K.: Production of lightning $\mathrm{NO}_{\mathrm{x}}$ and its vertical distribution calculated from three-dimensional cloud-scale chemical transport model simulations, J. Geophys. Res. Atmos., 115, D04301, https://doi.org/10.1029/2009JD011880, 2010. 
https://doi.org/10.5194/gmd-2022-39

Preprint. Discussion started: 4 March 2022

(c) Author(s) 2022. CC BY 4.0 License.

Pickering, K. E., Wang, Y., Tao, W. K., Price, C., and Müller, J. F.: Vertical distributions of lightning $\mathrm{NO}_{\mathrm{x}}$ for use in regional and global chemical transport models, J. Geophys. Res. Atmos., 103, 31203-31216, https://doi.org/10.1029/98JD02651, 1998.

Price, C. and Rind, D.: A simple lightning parameterization for calculating global lightning distributions, J. Geophys. Res., 97, 9919-9933, https://doi.org/10.1029/92JD00719, 1992.

Price, C. and Rind, D.: What determines the cloud-to-ground lightning fraction in thunderstorms?, Geophys. Res. Lett., 20, 463-466, https://doi.org/10.1029/93GL00226, 1993.

Price, C. and Rind, D.: Possible implications of global climate change on global lightning distributions and frequencies, J. Geophys. Res., 99, 823-833, https://doi.org/10.1029/94jd00019, 1994.

Price, C., Penner, J., and Prather, M.: $\mathrm{NO}_{\mathrm{x}}$ from lightning 1. Global distribution based on lightning physics, J. Geophys. Res. Atmos., 102, 5929-5941, https://doi.org/10.1029/96jd03504, 1997.

Romps, D. M.: Evaluating the Future of Lightning in Cloud-Resolving Models, Geophys. Res. Lett., 46, 14863-14871, https://doi.org/10.1029/2019GL085748, 2019.

Romps, D. M., Seeley, J. T., Vollaro, D., and Molinari, J.: Projected increase in lightning strikes in the united states due to global warming, Science (80-. )., 346, 851-854, https://doi.org/10.1126/science.1259100, 2014.

Schumann, U. and Huntrieser, H.: The global lightning-induced nitrogen oxides source, Atmos. Chem. Phys., 7, 3823-3907, https://doi.org/10.5194/acp-7-3823-2007, 2007.

Sudo, K. and Akimoto, H.: Global source attribution of tropospheric ozone: Long-range transport from various source regions, 112, https://doi.org/10.1029/2006JD007992, 2007.

Sudo, K., Takahashi, M., Kurokawa, J. I., and Akimoto, H.: CHASER: A global chemical model of the troposphere 1. Model description, J. Geophys. Res. Atmos., 107, ACH 7-1-ACH 7-20, https://doi.org/10.1029/2001JD001113, 2002.

Takemura, T., Egashira, M., Matsuzawa, K., Ichijo, H., O’Ishi, R., and Abe-Ouchi, A.: A simulation of the global distribution and radiative forcing of soil dust aerosols at the Last Glacial Maximum, Atmos. Chem. Phys., 9, 3061-3073, https://doi.org/10.5194/acp-9-3061-2009, 2009.

Tost, H.: Chemistry-climate interactions of aerosol nitrate from lightning, Atmos. Chem. Phys., 17, 1125-1142, https://doi.org/10.5194/acp-17-1125-2017, 2017.

Tost, H., Jöckel, P., and Lelieveld, J.: Lightning and convection parameterisations - Uncertainties in global modelling, Atmos. Chem. Phys., 7, 4553-4568, https://doi.org/10.5194/acp-7-4553-2007, 2007. 

climate change?, in: Third Conference on Meteorological Applications of Lightning Data, New Orleans, USA, 20-28 January 2008, 2.1, 2008

Watanabe, S., Hajima, T., Sudo, K., Nagashima, T., Takemura, T., Okajima, H., Nozawa, T., Kawase, H., Abe, M., Yokohata, T., Ise, T., Sato, H., Kato, E., Takata, K., Emori, S., and Kawamiya, M.: MIROC-ESM 2010: Model description and basic results of CMIP5-20c3m experiments, Geosci. Model Dev., 4, 845-872, https://doi.org/10.5194/gmd-4-845-2011, 2011.

Wild, O.: Modelling the global tropospheric ozone budget: Exploring the variability in current models, Atmos. Chem. Phys., 7, 2643-2660, https://doi.org/10.5194/acp-7-2643-2007, 2007.

Wofsy, S. C., Afshar, S., Allen, H. M., Apel, E., Asher, E. C., Barletta, B., Bent, J., Bian, H., Biggs, B. C., Blake, D. R., Blake, N., Bourgeois, I., Brock, C. A., Brune, W. H., Budney, J. W., Bui, T. P., Butler, A., Campuzano-Jost, P., Chang, C. S., Chin, M., Commane, R., Correa, G., Crounse, J. D., Cullis, P. D., Daube, B. C., Day, D. A., Dean-Day, J. M., Dibb, J. E., Digangi, J. P., Diskin, G. S., Dollner, M., Elkins, J. W., Erdesz, F., Fiore, A. M., Flynn, C. M., Froyd, K., Gesler, D. W., Hall, S. R., Hanisco, T. F., Hannun, R. A., Hills, A. J., Hintsa, E. J., Hoffman, A., Hornbrook, R. S., Huey, L. G., Hughes, S., Jimenez, J. L., Johnson, B. J., Katich, J. M., Keeling, R., Kim, M. J., Kupc, A., Lait, L. R., Lamarque, J. F., Liu, J., McKain, K., McLaughlin, R. J., Meinardi, S., Miller, D. O., Montzka, S. A., Moore, F. L., Morgan, E. J., Murphy, D. M., Murray, L. T., Nault, B. A., Neuman, J. A., Newman, P. A., Nicely, J. M., Pan, X., Paplawsky, W., Peischl, J., Prather, M. J., Price, D. J., Ray, E., Reeves, J. M., Richardson, M., Rollins, A. W., Rosenlof, K. H., Ryerson, T. B., Scheuer, E., Schill, G. P., Schroder, J. C., Schwarz, J. P., St. Clair, J. M., Steenrod, S. D., Stephens, B. B., Strode, S. A., Sweeney, C., Tanner, D., Teng, A. P., Thames, A. B., Thompson, C. R., Ullmann, K., Veres, P. R., Vizenor, N., Wagner, N. L., Watt, A., Weber, R., Weinzierl, B. Wennberg, P, Williamson, C J, Wilson, J C, Wolfe, G M, Woods, C T, Zeng, L H: ATom: Merged Atmospheric Chemistry, Trace Gases, and Aerosols, https://doi.org/10.3334/ornldaac/1581, 2018.

Zeng, G., Pyle, J. A., and Young, P. J.: Impact of climate change on tropospheric ozone and its global budgets, Atmos. Chem. Phys., 8, 369-387, https://doi.org/10.5194/acp-8-369-2008, 2008. 